\title{
黄河流域地质地表过程与重大灾害效应研究与 展望
}

\author{
兰恒星 ${ }^{1,2}$, 彭建兵 ${ }^{1 *}$, 祝艳波 ${ }^{1}$, 李郎平 ${ }^{2}$, 潘保田 ${ }^{3}$, 黄强兵 ${ }^{1}$, 李军华 ${ }^{4}$, 张强 $^{5}$
}

1. 长安大学地质工程与测绘学院, 西安 710054 ;

2. 中国科学院地理科学与资源研究所资源与环境信息系统国家重点实验室, 北京 100101;

3. 兰州大学资源环境学院, 兰州 730000;

4. 黄河水利委员会, 黄河水利科学研究院, 郑州 450003;

5. 北京师范大学地表过程与资源生态国家重点实验室, 北京 100875

* 通讯作者, E-mail: dicexy_1@chd.edu.cn

收稿日期: 2021-05-01; 收修改稿日期: 2021-08-12; 接受日期: 2021-08-18; 网络版发表日期: 2021-12-06

国家自然科学基金项目(批准号: 42041006、41790443)和中国科学院战略性先导科技专项项目(编号: XDA23090301)资助

摘要 黄河流域地质构造活跃、地貌演化迅速、气候区域分异显著, 流域重大灾害类型多、分布广、突发性强, 且灾害往往链生成链、致灾后果严重, 破坏黄河流域生态环境, 影响流域地质与生态安全. 目前, 大江大河流域地 质地表过程与重大灾害效应是地球科学研究的国际前沿与热点. 为此, 文章详细梳理了与黄河流域地质地表过 程、重大灾害效应、风险防范有关的国内外研究现状与发展动态, 探讨了研究趋势和面临的挑战, 分析了函需突 破的关键科学问题, 并基于地球系统科学思想提出了研究展望. 黄河流域地质地表过程与重大灾害效应研究的主 要方向有: 黄河流域地质、地表和气候过程及其联动孕灾机制, 黄河流域上游巨型滑坡形成机理及灾害链演化, 黄河流域中游黄土地区水土灾害机制与灾害链生效应, 黄河流域下游巨型洪灾发生规律及链生放大效应, 黄河流 域重大灾害风险防范. 亟待突破的关键科学问题为: 如何揭示地质、地表与气候过程耦合联动孕育重大灾害机 制, 如何阐明重大灾害与生态互馈效应, 如何构建基于人地协调的流域重大灾害风险综合防控体系。研究展望包 括: 以地球系统科学理论为指导, 突出学科交叉融合, 从“重建历史-聚焦现代-展望未来”的时间轴尺度揭示黄河流 域地质、地表与气候联动孕灾机制; 创新理论体系，从“地-域-河”的空间轴尺度阐明黄河流域重大灾害区域模 式、动力学机制、灾害链生与生态互馈效应; 突破技术瓶颈, 从“人地协调观”角度建立黄河流域综合风险评估模 型与防控理论, 形成“全流域覆盖、分区分带管控”应用示范格局, 保障流域生态地质安全, 为黄河流域生态保护 和高质量发展提供科学参考.

关键词黄河流域, 地质过程, 地貌演化, 重大灾害效应, 生态环境, 风险防范

\begin{tabular}{|ll}
\hline 中文引用格式: & 兰恒星, 彭建兵, 祝艳波, 李郎平, 潘保田, 黄强兵, 李军华, 张强. 2022. 黄河流域地质地表过程与重大灾害效应研究与展望. 中国科学: 地球科 \\
& 学, 52(2): 199-221, doi: 10.1360/SSTe-2021-0115 \\
英文引用格式: & Lan H, Peng J, Zhu Y, Li L, Pan B, Huang Q, Li J, Zhang Q. 2022. Research on geological and surfacial processes and major disaster effects in the \\
& Yellow River Basin. Science China Earth Sciences, 65(2): 234-256, https://doi.org/10.1007/s11430-021-9830-8
\end{tabular} 


\section{1 黄河流域重大灾害效应研究的战略意义}

黄河，中华大地上一条奔腾不息、生机勃勃的大 动脉，也是一条历经九磨十难的苦难河. 早在 1880 年, Nature报道称黄河为“中国的苦难(China's Sorrow)” (Guppy, 1880). 黄河流域的中华儿女世世代代“依存于 河、受制于河”，生生不息地“治理黄河、保护黄河”. 历经了上千年，这种苦难状态已经有了翻天覆地的变 化. 但目前黄河流域仍然是全球最脆弱的流域系统之
一(Hamblin和Christiansen，2004)，这种脆弱乃至苦难 状态的根本来源之一是流域内频发的重大灾害. 黄河 流域的重大灾害主要指上游的巨型滑坡灾害、中游的 水土灾害和下游的巨型洪灾(图1).

黄河流域横跨了世界上最年轻的青藏高原、正在 堆积的黄土高原和人口密集的华北平原(图1), 流域内 地质构造活跃、内外地质动力作用强烈、地貌演化过 程特殊, 灾害发育规律复杂, 是我国地质环境最复杂、 生态环境最脆弱的地区之一(苏人琼和杨勤业，1996;

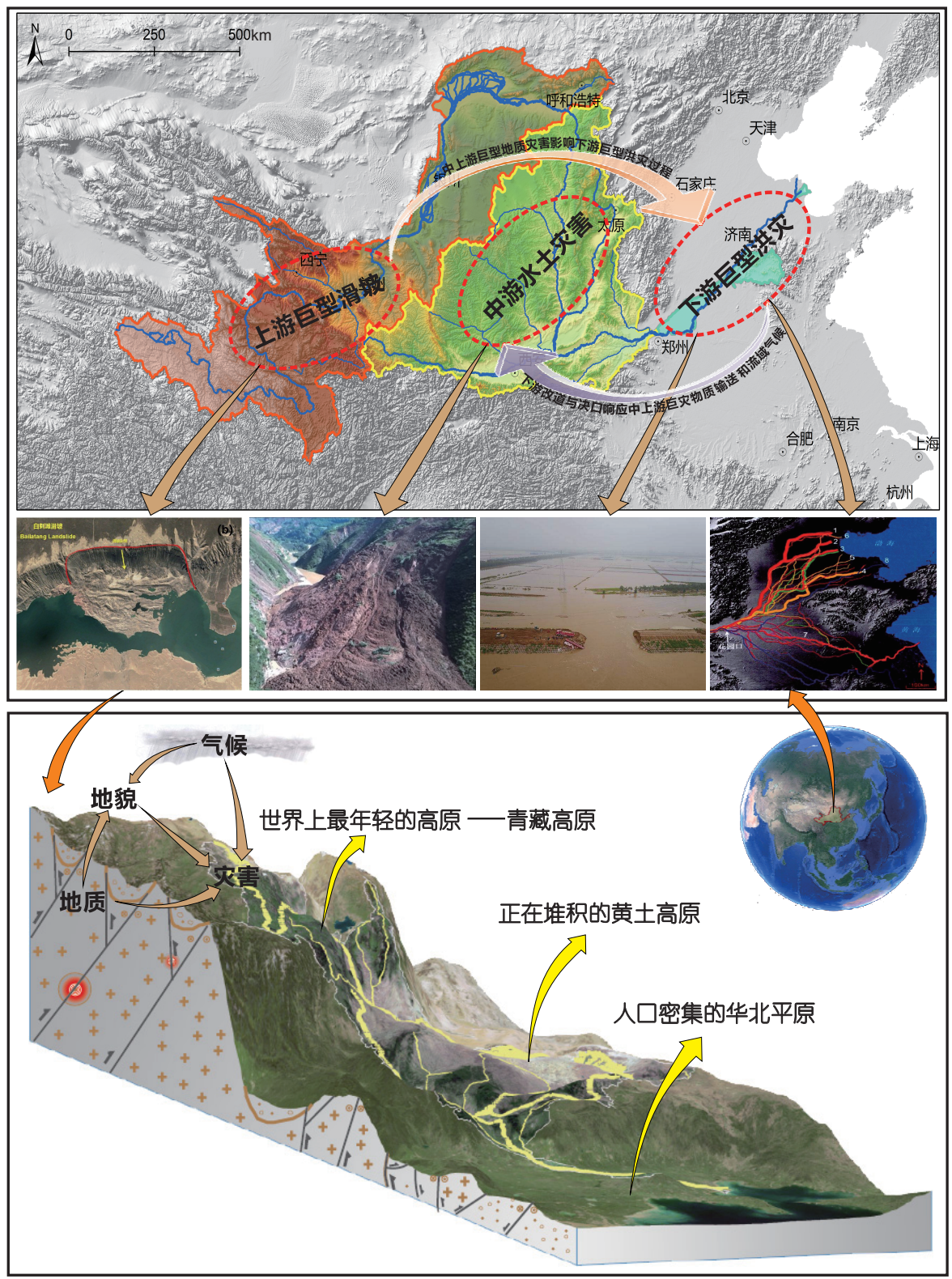

图 1 黄河流域横跨不同地貌单元及重大灾害 
彭建兵等, 2004, 2020). 同时, 黄河流域又是一个复杂 的巨系统, 黄河流域灾害问题表象于河, 形成于域, 根 植于地(彭建兵等, 2020), 上下游灾害系统的各个部分 在时间和空间上存在复杂的相互作用(图1), 这导致了 黄河流域重大灾害具特殊性和复杂性，灾害风险影响 显著(Qiu, 2014).

黄河流域重大灾害分布广、类型多、突发性强, 且灾害往往链生成链、致灾后果严重. 这些重大灾害 直接破坏黄河流域生态环境, 影响黄河流域安全, 挑 战黄河流域的长久宜居性，制约着黄河流域生态保护 和高质量发展.

(1) 重大灾害直接破坏黄河流域生态环境. 黄河流 域构成我国重要的生态屏障，但黄河流域上游局部地 区生态系统退化、水源涵养功能降低; 中游黄土高原 黄土水土灾害频发、水土流失严重(邵明安和上官周 平, 2000); 下游泥沙淤积、河道抬高、洪水灾害频发. 以上重大灾害直接破坏黄河流域生态环境, 在一定程 度上也加重了灾害的影响程度，流域生态环境问题已 经成为社会经济高质量发展、生态文明建设的最大制 约瓶颈，亟待从根本上解决重大灾害与生态环境退化 问题.

（2）重大灾害直接影响黄河流域安全和高质量发 展. 黄河流域是我国“一带一路”倡议、“新时代西部大 开发”、“黄河流域生态保护和高质量发展”等重大国 家战略实施的关键区域，流域内城镇建设、线性工 程、能源开采、水利水电等工程建设规模大、范围 广、速度快, 快速改变着地质地貌和生态环境(程钰 等，2019). 但由于工程与地质互馈易诱发工程灾变, 使得重大灾害直接威胁重大工程安全，危及流域内工 程设施的安全运营, 直接影响黄河流域安全, 进而影 响高质量发展.

(3) 重大灾害严峻挑战黄河流域长久宜居性. 黄河 流域下游历史上曾发生了 1500 多次决口事件，以及至 少26次大型改道事件(沈怡等, 1935; Wang和 $\mathrm{Su}, 2011$ ), 影响人类发展空间及生存轨迹, 制约流域城镇发展. 黄 河中游地质灾害发育密集，占全国地质灾害约 $1 / 3$ (彭 建兵等, 2016). 仅陕北地区就分布有黄土崩塌23000多 个、黄土滑坡16600多个，密度超过10个 $\mathrm{km}^{-2}$ (Zhuang 等, 2018a), 易造成群死群伤和重大财产损失, 制约城 镇发展, 影响长久宜居性. 黄河上游地区分布着大量的 巨型滑坡, 其形成机理复杂, 危害巨大, 成因至今未解,
且部分仍在复活. 部分滑坡历史上曾堵塞黄河, 并溃决 形成过超大洪水(Wu等，2016)，影响中华民族的文明 演化和社会经济发展.

然而, 目前针对这些重大灾害的动力学演化机理 及其链生效应缺乏深入研究, 尚无重大灾害与生态环 境互馈分析理论及流域重大灾害综合风险防控理论技 术. 黄河流域重大灾害效应与风险防范水平已不适应 “一带一路”倡议、“新时代西部大开发”、“黄河流域 生态保护和高质量发展”等重大国家战略实施的实际 需求, 制约黄河流域高质量发展. 因此, 开展黄河流域 地质地表过程与重大灾害效应研究, 保障流域地质安 全与生态安全，促进人地协调，服务“黄河流域生态保 护和高质量发展”等重大国家战略需求, 具有重要的理 论意义与实践价值.

\section{2 黄河流域地质地表过程与重大灾害效应 研究现状}

世界上著名的大江大河流域跨度长、覆盖范围 广, 往往跨越多个不同地质地貌单元, 承受多个圈层的 相互作用，其地质地表过程与重大灾害效应已成为当 前地球科学研究的国际前沿与热点问题. 然而, 相比 国内外典型流域，黄河流域公开发表的国际研究成果 要少得多, 黄河流域重大灾害研究总体深度和广度与 其他重要流域相比有较大差距. 本文详细梳理了与黄 河流域地质地表过程与重大灾害效应研究有关的国内 外研究现状与发展动态.

\section{1 黄河流域地质地表过程研究}

黄河流域地质、地表、气候过程长时间序列耦合 作用过程不清, 全过程联动孕灾机制不明.

灾害是一个多因素共同作用的、长期演化的产物 (Cruden和Lan, 2015). 黄河流域地质过程活跃, 地表过 程迅速, 气候过程多变, 因此灾害多发, 且具有很强的 特殊性. 国内外学者针对黄河流域地质地表过程开展 了长期深入的研究.

（1）重建流域地貌形成发育和演化过程。流域地 质、地表、气候过程本质上是一个长时间序列的问 题，侵蚀、搬运和堆积作用串联着整个流域( $\mathrm{Yu}$ 等, 2017；Immerzeel等，2020). 国外典型河流流域的形成 发育历史和地貌演化过程均已被成功恢复(Blum和Pe- 
cha, 2014; Hoorn等, 2010; Faccenna等, 2019). 虽然我国 黄河某些河段的形成发育研究已取得了显著成果(Pan 等, 2011, 2012; Hu等, 2016, 2017), 但仍然没有上升到 通过关联上、中、下游发育历史来构建整个河流地貌 演化过程的研究层面(潘保田等, 1996). 这主要是由于 黄河上游不同河段发育历史差异大，单一测年方法无 法全流域覆盖(Pan等, 2009; Craddock等, 2010); 有关 黄河上游盆地堆积时的水系格局在向现代深切河谷水 系演化的重组过程的认识不一(赵振明和刘百簏, 2005); 在缺乏年代框架的背景下，黄河上游不同河段 阶地序列的划分不够详细. 目前关于黄河上游形成时 代与过程仍不够明晰，难以重建中、上游联动的形成 发育过程时序，阐明流域孕育重大地质灾害的地貌演 化背景仍面临挑战.

(2) 揭示构造隆升对地貌的控制作用. 黄河上游青 藏高原隆升和新构造运动不仅对河流形成发育与地貌 演化产生了严重影响(潘保田等, 1996), 且与流域内地 质灾害联系密切(彭建兵等, 2004; Xu等, 2017). 青藏高 原东北部构造变形最为强烈、活动断层分布最为密 集、地震活动频繁(王思敬, 2002; 张培震等, 2013; 兰 恒星等, 2016). 在上述地质构造背景下, 黄河中上游切 开积石峡后不断向高原内部延伸(Craddock等，2010), 形成了能够代表中上游宏观构造格局的典型盆-山耦 合系统. 然而, 目前在重建黄河上游盆山演化过程的认 识上仍存在分歧(van der Woerd等, 2002; Mériaux等, 2005; Hu等, 2012; Jia等, 2017), 无法开展整个黄河中 上游构造隆升和新构造运动的时空对比. 另外, 黄河中 上游长时空尺度的古地震研究不足, 对主要断裂带的 研究基本基于地貌记录的变形特征和破坏模式( $\mathrm{Su}$ 等, 2019), 缺乏与古地震数据的关联对比(Larsen和Montgomery, 2012; Guo等, 2016). 目前, 对代表性盆-山系 统和主要断裂带时空演变过程的认识研究, 还不足以 厘清黄河中上游构造隆升对地貌的控制作用，更无法 有效搭建其与流域地质灾害的响应关系.

(3) 黄河流域重大灾害过程联动关系研究. 黄河下 游由于地势平缓, 下游河道比降普遍较低致使持续淤 积, 以至决口、溃堤、改道等灾害频繁发生(Phillips和 Jerolmack, 2016). 在全球气候变化与灾害关联越发紧 密的背景下, 以往研究仅关注流域气候急剧波动对河 流下游灾害的触发作用还远远不够(Blöschl等，2019). 已有研究发现, 河流上游发生的大型滑坡、泥石流、
冰川跃动、水系袭夺重组等快速地质和地貌过程能够 直接导致河道主槽迁移, 产生形态上的变化(Clift和 Blusztajn, 2005; Larsen和Montgomery, 2012; Glade等, 2019), 最终可能引发下游改道、溃堤洪水等灾害(Valenza等，2020). 然而，从目前已有关于黄河下游决 口、改道等研究来看, 其记录的时间尺度仅停留在历 史时期，短于流域气候变化和中上游地质灾害发生的 时间尺度(Wu等, 2016). 目前, 如何建立流域上中下游 的联动关系, 是探讨流域灾害成因和孕灾过程的最新 发展趋势(Cook等, 2018); 如何建立起上中下游灾害之 间的联系，已成为揭示下游改道、决口触发过程和原 因所面临的最大技术瓶颈.

综上所述, 明晰地质过程(百万年计)-地表过程(十 万年计)-气候过程(万年计)是揭示黄河流域耦合孕育 重大灾害的基础. 梳理流域构造隆升与新构造运动的 时空演变过程, 认清其对地貌的控制作用, 重建黄河 中上游形成发育历史与地貌演化过程，建立河流发育 与重大灾害时空分布的对应关系，同时提升地质灾害 空间分布差异性的解译方法和技术水平，并基于过程 联动的思路，找到上中下游之间有效的物质联系，才 能在黄河流域的孕灾机理上取得理论突破.

\section{2 黄河流域上游巨型滑坡研究}

黄河流域上游巨型滑坡形成机理及灾害链演化研 究表明, 基于孕灾背景时空差异性的巨型滑坡动力学 机制与生态地质环境安全理论欠缺.

黄河上游巨型滑坡密集，具有“突发性强、落差 大、动力强、规模大”等特点, 历史上曾多次发生堵塞 黄河事件(Dong等, 2014; Zhang Y等, 2019). 因此, 巨型 滑坡形成机理与灾害链生效应一直以来是工程地质界 关注的焦点. 目前, 国内外学者针对巨型滑坡主要围绕 以下几个方面开展研究.

（1）巨型滑坡时空分布特征. 黄河上游长期的构造 活动是引起黄河上游巨型滑坡空间集中分布的内因 (周保等, 2014). 研究表明, 超过90\%的大型滑坡发生于 断裂带两侧 $5 \mathrm{~km}$ 范围内(Zhao等, 2019), 尤其是断裂带 交汇巨型滑坡处分布密集(孙延贵等, 2007). 巨型滑坡 具有空间上沿河道分布的特点，以龙羊峡至刘家峡河 段巨型滑坡最为典型; 巨型滑坡分布还在时间尺度上 与气候变化相关. 晚更新以来，黄河上游巨型滑坡主 要集中在五个时期发育，其中四个时期发育的滑坡与 
暖湿气候和气候变化的快速转型期有关，尤其是与冰 雪融水、高原季风增强有关(殷志强等, 2016; 郭小花, 2017). 以上研究主要面向万年尺度的地质历史，从巨 型滑坡演化与构造、气候、地震、河道侵蚀的相关性 展开研究. 然而, 在百年时间尺度内, 在考虑黄河演化 的区域背景与多因素耦合作用下，黄河上游巨型滑坡 的时空聚集、区域性群发模式、周期性演化的研究仍 显不足.

(2) 巨型滑坡形成机理. 随着青藏高原隆升和黄河 的下切, 在强弱交替中滑坡活动呈不断加重趋势(王思 敬，2002). 青藏高原隆升控制着黄河的形成演化和岸 坡的形成演化，也控制着区内巨型滑坡的形成(李小林 等, 2011). 同时, 强震与极端气候事件是诱发巨型滑坡 发生的重要因素(兰恒星等, 2013; Zhao等, 2019), 如黄 河上游早中更新世以来的古滑坡和现代滑坡大多数发 生在暖湿期(殷志强等, 2013). 河流侵蚀是巨型滑坡发 生的另一个必要条件(赵无忌等, 2016). 研究表明, 全 新世暖湿气候黄河侵蚀切割作用加强是研究区晚期滑 坡发生的主要原因(蔡俊超, 2014), 且未来全球变暖导 致冰川融水在冰川消退期可能诱发巨型滑坡(Kellogg, 2001). 地质结构对巨型滑坡变形破坏过程具有非常明 显的控制作用(黄润秋, 2003; 兰恒星等, 2019), 如黄河 上游积石峡地区巨型岩质滑坡模式与规模明显受控于 软弱夹层作用(彭建兵，1997). 然而，目前在考虑黄河 演化的区域背景与多因素耦合作用下，巨型滑坡周期 性演化、区域性群发模式研究仍不足.

(3) 巨型滑坡复活的动力机制. 巨型滑坡动力学形 成演化过程与强震过程滑带动力扩容和水击效应(裴 向军等, 2018)、滑体抛搠分离与铲刮(刘晓等, 2012)或 饱和液化(殷跃平等, 2000)等效应关系密切. 这些效应 导致摩擦系数降低并加剧高速远程效应(刘汉超和张 倬元，1986), 产生能量交换、气垫层、超孔隙水压力 及滚动摩擦减阻等. 黄河上游巨型滑坡的形成演化具 有其独特性，黄河侧蚀下切作用与软弱夹层强度劣化 减弱了巨型滑坡的抗滑力，地震作用提高了巨型滑坡 下滑力并减弱了抗滑力(Zhao等, 2019). 另外, 不良地 质构造条件和破碎滑坡体是巨型滑坡形成与复活的主 要内因(Dai等, 2005; Huang, 2009), 库水位变化、降水 和人类工程活动是巨型滑坡活动的主要外因( Lan等, 2004; Ronchetti等, 2010; Rodríguez-Peces等, 2011). 众 多学者在滑坡动力机制和过程研究中均考虑了斜坡渗
流场和应力场作用(刘汉超等, 1990; 兰恒星和伍法权, 2000；唐辉明等，2002；兰恒星等，2003；易庆林等， 2017; Wu和Lan, 2019). 但是, 复杂因素耦合作用下不 同地质结构的巨型滑坡复活机理及其动力学模式与理 论模型仍缺乏.

(4) 巨型滑坡灾害链生效应研究. 在构造运动、地 震、极端气候等作用下，黄河上游发育了大量巨型滑 坡与堰塞湖(魏占胥等, 2017), 堰塞湖溃决引起次生灾 害甚至摧毁人类文明(Dong等, 2014; 张玉柱等, 2017). 同时，巨型滑坡堵河-堰塞湖-溃坝-再堵河演化过程受 气候影响具有周期性(Soldati等, 2004; 郭小花, 2017). 目前, 关于此方面研究以单一的数值方法为主(Liu C 等，2018)，这不能反映黄河上游巨型滑坡沉积物运动 的速度变化、制动与分布规律、灾害链致灾放大效 应. 缺乏巨型滑坡灾害链生与河流变迁的互馈机制研 究, 堰塞湖-洪水灾害链生过程难以模拟再现. 同时, 研究表明，巨型滑坡灾害链造成生态安全风险(Geertsema等，2009). 虽然国内外学者开展了生态工程护坡 方面研究, 但极少考虑滑坡对生态扰动的影响(Geertsema和Pojar, 2007)，巨型滑坡灾害链生效应导致的生 态地质安全问题研究仍极其缺乏(彭建兵等, 2020). 目 前，仍缺乏黄河流域上游巨型滑坡灾害链生与生态互 馈机制研究, 缺乏流域巨型滑坡-堰塞湖-溃坝洪水灾 害链生过程模拟再现.

综上所述，黄河上游巨型滑坡研究在以下四个方 面仍面临挑战, 需要进一步的研究突破: 黄河上游巨 型滑坡时空分布模型、黄河上游巨型滑坡群发机制、 黄河上游巨型滑坡动力学机制与灾害链生效应、黄河 上游巨型滑坡复活机理与生态地质安全.

\section{3 黄河流域中游黄土水土灾害研究}

黄河流域中游黄土水土灾害群发机制与灾害链生 效应研究表明, 水土灾害群发机理认识有待提高, 灾害 链与生态环境的互馈效应评价亟需开展研究.

国内外学者高度广泛关注水土灾害群发机制与灾 害链生效应研究(Schwab等, 2008). 黄河流域中游由于 沉积环境、地质地貌孕灾过程特殊(郭正堂等，1996; Peng等，2019)，崩滑流等水土灾害往往呈现出流域集 中性、群发性与链生特征. 目前国内外学者针对水土 灾害主要围绕以下几个方面开展研究.

(1) 水土灾害群发规律与群发机理. 山洪与崩滑流 
是黄河流域中游水土灾害的主要形式，极端降雨下山 洪形成与流域内崩滑流水土灾害紧密关联(Peng等, 2015). 山洪在沟道-流域-区域等不同空间尺度间的传 递、转化特征，降雨特征与山洪分布关系的多尺度问 题等仍是当前研究的薄弱之处(Saharia等, 2016; He等, 2018). 黄河流域中游黄土高原地区崩塌、滑坡和泥石 流等呈现出区域性分布特征，地质和地貌差异是崩滑 流群发的必要条件(胡江春等, 2018), 地震和大气降水 为崩滑流提供强大动力条件(张茂省等，2013; 彭政奎 和杨东强等，2019； Fu等，2019)，植被不发育和人类 活动频繁也是崩滑流群发性强的重要因素(王家鼎和 惠泱河, 2002; 武彩霞等, 2011). 基于多源高分遥感、 无人机等监测技术手段的发展，国内外学者针对土水 灾害的动力机制研究，已经从定性方法逐渐发展为定 量方法和数学及力学耦合分析方法(兰恒星等, 2007 ; Lan等, 2007, 2010；Li等，2020). 但是，水土灾害成灾 过程与流域气候、水文及地质条件的互馈作用存在时 间和空间尺度的差异性，其动力过程研究仍依赖于精 确的多尺度物理模型及岩土体的力学参数. 黄河流域 降水时空分配波动较为剧烈，而目前流域中游地区崩 滑流群发时空变异性与成灾因子识别模型中缺少对植 被和人类活动的考虑.

(2) 水土灾害链生效应研究. 黄土灾害往往以灾害 链形式出现, 从一个灾种迅速转化为另一个灾种, 灾种 之间呈现出因果关系(姜程等, 2019). 黄土灾害链的链 式结构可归纳为: 水、力的扰动作用-土体湿陷变形 土层沉降-地裂缝-崩塌滑坡-泥流(朱兴华等, 2017). 但 目前还没有关于黄土灾害链演化机制和动力学过程的 系统性研究成果, 零散的研究主要集中在: 沉降湿陷一 地裂缝-崩滑转化机制的研究(Peng等，2017)、滑坡泥 石流转化机制的研究(Zhang等，2013)等方面. 而灾害 链在时间与空间连续扩展往往造成累积放大致灾效应 (Cui等, 2013), 导致损失远远超过单一灾害, 为此学者 们建立了各类灾害链危害评估的模型公式(Hungr等, 2005; 朱平一等, 2000). 而黄土水土灾害链复杂多变, 研究表明链式类型多(Zhang F等, 2019)、演化过程特 殊复杂、运动距离远、影响范围大(Peng等, 2015). 目 前，尚缺失能够全面反映孕灾条件、运动过程约束(如 沟道水文条件及沟道边界)、滑动物质“流固相变”的 黄土水土灾害链生效应及模式评价模型。

(3) 水土灾害生态环境效应. 生态与灾害的互馈机
制是一个极为复杂的问题( $\mathrm{Fu}$ 等, 2017). 传统观点认为 水土保持工程有效降低了地表径流，植被根系对土体 加固效应遏制了面状水土流失及浅层崩滑 (Preti, 2013; de Jesús Arce-Mojica等, 2019), 促进了生态环境 向好. 但生态系统在缓冲自然灾害作用方面仍然存在 不确定性(Kobayashi和Mori，2017)，如森林蒸腾量增 加, 导致较高耗水量(Sun等, 2020), 使得土地变得更加 干燥(Yan等，2018)，造成径流量显著减少(Bao等, 2019); 当植被根系加固深度远小于深层滑坡滑面埋深 时，植被根系与土壤形成大孔隙系统会诱发浅层滑坡 产生，促进水土灾害发生(Gou等，2020). 但同时滑坡 也是生态系统演化和生物多样性的驱动力(GonzalezOllauri和Mickovski，2017; Gomes等，2020；Lopes等， 2020)，如黄土高原地区的土水灾害(Zhang等，2009; Wang等, 2015; Zhuang等, 2018b)造成了局部生态环境 的进一步恶化. 目前, 量化水土灾害与生态环境的互馈 关系，明晰生态与灾害互馈机制是当前水土灾害生态 防治研究的核心工作.

综上所述，黄河流域中游黄土水土灾害研究在以 下三个方面仍面临挑战，需要进一步研究突破：地貌气候耦合作用下黄土崩滑流灾害群发机理、黄河流域 中游水土灾害链生效应、水土灾害与生态环境互馈 效应。

\section{4 黄河流域下游巨型洪灾研究}

黄河流域下游巨型洪灾发生规律及放大效应研究 表明，复杂结构河道巨型洪灾发生规律及放大效应复 杂, 预测方法和防控技术仍不成熟.

在多因素作用下，洪涝灾害成为黄河下游地区发 生最频繁、破坏性最强的灾害形式之一。黄河下游同 频率洪水条件下洪灾放大效应明显, 洪灾呈现“决口频 次高、淹没面积广、链生效应复杂、危害重、预警 难”等特点. 目前, 国内外学者针对巨型洪灾主要围绕 以下几个方面开展研究.

(1) 洪灾时空演变规律. 众多学者(黄河水利委员 会, 1959; 张含英, 1982; 钮仲勋, 1993; 邹逸麟, 2006) 对黄河下游决溢改道的频次、决口地点(徐福龄, 1979; 钱宁，1986)基本达成共识. 近千年来黄河下游 决溢的时空演化分析研究表明，黄河下游决口的时空 演变与下游河道演化有着密切的关系(Zhang和Fang, 2017), 并且数次改道的地理特征不同(Wang和 $\mathrm{Su}$, 
2011). 降水多是黄河中下游决口、漫溢和改道频率高 的主要诱因(Wang和 Su, 2013), La Niña事件也对黄河 下游决溢产生重要影响(Xu和 Li, 2019). 目前, 黄河下 游历史大洪水形成原因、淹没特征及灾情表现已被 重点分析和重建(王涌泉, 2007; 胡贵明等, 2015; Storozum等，2020), 为研究巨型洪灾成灾模式提供了资 料. 但是，随着降雨带逐渐北移(丁一汇等，2013; Yang等, 2015; Xu和 Li，2019), 呈现未来气候变化背 景下黄河流域下游洪水损失风险加剧的趋势 $(\mathrm{He}$ 等, 2015). 然而, 不同致灾因子之间的共同作用(极端暴雨 洪水直接引发洪灾、泥沙淤积造成的洪灾、决堤引 起大的洪灾)造成的风险远大于单一灾害风险影响. 当前，单致灾因子造成的洪灾时空演化规律研究，已 无法有效应对雨带北移等造成的黄河下游巨型洪水 时空演变的复杂特征.

(2) 巨型洪灾形成机制. 洪灾形成过程受到天气系 统、陆地表面系统和人类活动的共同影响(夏军和石 卫, 2016), 包含影响暴雨的天气气候系统以及影响径 流形成的地形、植被、土壤等下垫面要素( Gou等, 2020). 因黄土高原土质疏松、侵蚀冲刷严重、径流含 沙量大, 最终导致黄河下游形成地上悬河, 使黄河下游 洪水形成机制不同于其他河流，如泥沙淤积导致洪灾 损失的链式放大作用尤为明显(倪晋仁等，2004). Labat等(2004)分析了全球221条河流的历史资料, 发现全 球 $49 \%$ 的地区百年一遇洪水将呈显著增加趋势(Hirabayashi等, 2013). 黄河流域观测资料表明, 1951 2018 年间流域极端降水频率明显增加，尤其是中下游地区 (Miao等，2019; 马柱国等，2020). 然而，包括降雨强 度、历时和范围的致灾因子均存在不确定性. 另外, 黄 河径流含沙量大, 加之人类不断侵占河道, 导致黄河下 游形成地上悬河、游荡型河流. 因此, 目前复杂环境变 化下黄河下游巨型洪灾形成机制需进一步明确，其链 生过程及放大效应动态辨识研究不足.

(3) 巨型洪灾下悬河突出河段溃决风险. 随着黄河 下游河槽严重萎缩, 二级悬河加剧, 平滩流量减小, 大 洪水滩区流量陡增, “横河”、“斜河”、“滚河”、顺堤 行洪概率增大，加之堤基条件复杂、堤身隐患难查, 极大增加了堤防的“溃决”风险(张金良等, 2018), 且在 洪峰流量增大的情况下河床高度将继续升高(Schuurman等, 2018). 堤防风险评价是判定悬河段溃口概率及 其发展趋势、采取防控措施和应急决策的关键和基础
(王开拓, 2018). 目前, 堤防工程风险的研究已从传统 单项风险向堤防综合风险、系统风险转变(刘高峰等, 2019); 防洪策略也实现从“唯堤论”到“多元化工程措 施”, 再到 “工程措施与非工程措施相结合”的转变(陈 天慧和田耀, 2017). 另外, 若干研究将风险理论融入 堤防优化设计(Tung和Mays, 1981), 提出了堤防风险评 估方法(马晓忠等，2015)和堤防破坏概率量化方法 (Lendering等, 2018), 并成功用于防洪实践. 但是, 黄 河下游河道结构特殊, 边界条件差别较大, 特别是长时 间尺度河道-流量的动态互馈会引起河势游荡和悬河. 针对巨型洪灾下悬河段堤防“偎-渗-冲-溃联动”的溃决 机理、溃决风险和预测理论、融合“查-测-抢-护”的防 控技术等的关键问题亟待解决.

（4）洪水灾害情景模拟及风险应对，洪灾的情景 模拟受气候变异性等复杂多因素的影响. 国外学者通 过集水区降雨径流模型和二维水动力模型, 来模拟洪 水的淹没区域(Anselmo等, 1996), 通过对洪水水文、 水动力模型耦合, 计算洪水淹没面积(Nunes Correia 等, 1998), 通过随机洪水风险模型(Apel等, 2004), 建 立洪水风险指数, 绘制出洪水风险图(Sinha等, 2008). 针对洪水演进，刘燕华等(2008)根据黄河淤积自然发 育规律, 提出了黄河下游人工改道可能的后备流路. 张向萍等 $(2019,2020)$ 基于平面二维水流-泥沙数学模 型、实体模型以及情景分析、GIS空间分析技术，分 析了黄河下游宽滩区面对重大洪涝灾害情景的物理 暴露性. 李军华等 $(2018 \mathrm{a}, 2018 \mathrm{~b}, 2019,2020)$ 基于实 体模型开展黄河下游小浪底至陶城铺河段不同洪水 模拟试验, 分析了不同情景下黄河下游洪水泥沙演进 规律. 也有学者通过数值模型模拟洪水演进, 构建洪 水风险变化(Kim等, 2012), 进行致灾风险评估(Ernst 等, 2010). 因此, 未来在足够的历史数据及高精度遥 感数据基础上, 采用数学模型对下游洪灾进行情景模 拟和过程再现, 并针对巨型洪灾对生态环境的影响提 出应对措施, 成为黄河巨型洪灾研究迫切需要解决的 问题.

综上所述，黄河流域下游巨型洪灾研究在以下四 个方面仍面临挑战, 需要进一步研究突破: 黄河流域 下游巨型洪灾时空演变规律、黄河流域下游巨型洪灾 形成机制及其驱动因子、巨型洪灾下黄河下游悬河段 溃决风险预测、黄河流域下游巨型洪灾情景模拟与过 程再现. 


\section{5 黄河流域巨灾风险防范研究}

黄河流域重大灾害风险预估面临“源辨不准、综 合性欠缺”, 风险防范面临“人地协调不足、智能化低” 等问题.

黄河流域是全球受重大灾害风险影响最显著的区 域之一(Qiu, 2014). 黄河流域灾种多样, 且不同灾种之 间、承灾主体之间，以及巨灾与承灾体之间存在复杂 的交互联动关系, 灾害风险防范难度大.

(1) 在巨灾风险源判识方面: 随着遥感与地理信息 技术的发展，以地球观测技术为核心的灾害风险源判 识先进技术方法逐渐出现与完善(Dai等，2020)，并对 黄河流域若干巨灾成功实施了提前预警。然而，黄河 流域造成重大伤亡的灾害事件仍不断发生，表明黄河 流域巨灾风险提前预判仍是挑战(Zhang Y等，2019). 黄河流域重大灾害孕育机制和发育规律不明，具有很 强的隐蔽性; 气候环境变化和人类营力扰动作用下重 大灾害响应机理复杂，具有很强的突变性; 地质地 貌、气候与人类工程活动多过程作用下灾害链演变机 制多变、灾害联动过程多样, 具有一定的随机性(彭建 兵等, 2014). 因此, 黄河流域巨灾潜在风险源判识目前 仍存在巨大挑战.

(2) 在巨灾风险评估方面: 近年来，灾害风险评估 逐渐产生由主要考虑因素指标(Zhao等，2020)到考虑 灾害动力学过程(Lan等，2013a，2013b)、由定性转向 定量(Lan等, 2013b)、由单灾种转向多灾种等趋势. 然 而，当前的多灾种风险分析多采用各灾种风险叠加的 方式(Thierry等，2008; Zhou等，2015; Pourghasemi等, 2020)，甚少考虑多灾种交互联动的综合风险(Kappes 等, 2012). Reviews of Geophysics发表综述性论文系统 地指出不同灾害之间交互与联动的普遍性和重要性 (Gill和Malamud, 2014). 然而，当前对黄河流域灾害风 险评估工作仍然以单区域、单灾种为主(赵咸榕, 1998; Derbyshire，2001；刘燕华等，2006；张春山等， 2006; 唐亚明等, 2011; 魏刚, 2013; Guo等, 2018). 因此, 仍亟需基于不同巨灾以及不同承灾主体的联动机制, 发展适合于黄河流域的多区域、多灾种、多主体联动 的综合风险评估模型.

(3) 在巨灾风险防范理念方面: “灾害系统”是“人 地关系系统”的一种, 而人地关系系统研究的核心目标 是协调人地关系(史培军, 2009). 当前, “灾害风险防范
的根本目标旨在实现人地协调发展”这一认识正在逐 渐形成. 例如, 王思敬(1997)指出灾害风险防范的根本 目标旨在实现人地协调发展，Lan等(2013b)提出任何 风险阈值必须是各风险主体协调的结果，史培军等 (2019)则将“地理协同论”应用于综合灾害风险防范， 以践行从理解“人地关系”到设计“人地协同”的转变. 欧盟“SafeLand”计划也提出了“与灾害风险共生(living with landslide risk)”的口号, 其宗旨也是协调人灾关系, 而不是消除或逃避灾害. 很多研究也已提出了符合人 地协调理念的具体灾害风险防范措施(Bradley等, 2019), 例如，通过间隔种植避免高地下水位连续面的 形成, 进而阻断滑坡形成, 这一风险防范措施并不是简 单的不种植、不灌溉，而是在保证经济发展的同时实 现灾害防治. 黄河流域受到生态先天脆弱性与经济发 展迫切需求的双重压力(李小建等, 2020), 但目前关于 黄河流域灾害风险防范研究，并未从人地协调理念提 出具体的方法技术(张茂省, 2013). 现有灾害风险研究 与人地关系研究仍处于割裂状态，基于人地协调的灾 害风险防范理论技术体系尚未形成. 因此，仍需在理 解黄河流域“人-灾-经济-生态”交互机制与过程的基础 上，建立适宜于黄河流域的基于人地协调理念的巨灾 风险防范理论技术体系.

(4) 在巨灾风险防范平台方面: 先进高效的平台是 实施风险防范的有力保障. 大数据在灾害领域得到广 泛应用(Lan等, 2007; Khan等, 2020), 黄河流域巨灾风 险大数据涉及地学多领域、空间范围跨越多区域，具 有多源异构、跨层级和跨时空尺度的突出特点，为应 对挑战，亟需建立能支撑黄河流域巨灾风险的大数据 管理平台. 大数据使传统的风险应急管控行为模式从 “经验驱动”向“数据驱动”转变(刘艺等, 2018). 在这一 转变过程中, 应急预案的智能研判(Ergu等, 2016)和应 急事件的态势分析是关键. 但当前应急预案“案例匹配 事件”算法局限于某一特定场景或基于某些特定信息， 没有建立多源数据与应急事件案例的智能匹配(Song 等，2020). 黄河流域巨灾风险的应急管控是一个开放 的复杂巨系统，具有多主体、多要素、多层级、多变 性特征. 虽然目前在应急事件情景-应对方面开展了因 子-状态-事件的三层情境网络模型以及情景-推演方法 体系研究. 但这些情景-应对模型基于大数据驱动的基 础不够,在预测评估模型的集成计算方面支撑不足. 因 此，亟需研发集成风险判识、动态监测、综合评估、 
防范决策的黄河流域巨灾风险防范智能综合平台.

综上所述，黄河流域巨灾风险具有多区域、多灾 种、多主体联动综合的独特性，其风险源判识、风险 评估与风险防范研究仍面临重大挑战.

\section{3 黄河流域地质地表过程与重大灾害效应 研究发展趋势和面临挑战}

由上可见，黄河流域地质地表过程与重大灾害效 应研究是一个系统性科学问题, 需以地球系统科学理 念为基础，从流域系统整体性出发，揭示地球圈层相 互作用下黄河流域“大区域范围、长流域跨度、长时 间序列”的重大灾害效应与生态安全问题。其中，地 质、地貌与气候的链接关系，重大灾害与生态环境的 互馈关系，流域风险与人地安全的协同关系，将成为 研究热点与前沿难点:

\section{1 揭示黄河流域复杂联动的地质地表过程}

虽然国内外学者围绕黄河流域地质过程与地貌演 化开展了长期深入的研究，但目前仍为“分段孤立”的 研究现状(图2). 流域地质、地表、气候长时间序列耦
合作用过程不清，缺少全流域过程联动的长时间序列 重建，成为制约黄河流域地质地表与气候联动孕灾机 制研究取得突破进展的瓶颈。

黄河流域“重大灾害效应问题”是地球深部过程与 人类活动强烈影响的地球表层动力系统相互作用与转 化的产物, 深部地质过程、地貌演化与气候变化耦合 孕育着重大灾害．黄河流域上游地质过程活跃，青藏 高原隆升和新构造运动对河流形成发育与地貌演化产 生了重大影响, 是流域巨型灾害孕育的场所; 黄河中游 地表过程快速, 地貌类型多样, 气候分异显著, 导致水 土灾害频发; 黄河下游地势平坦广衰, 黄河改道、溃堤 洪水等灾害和中上游的极端气候、重大灾害间联系密 切. 可见, 虽然黄河流域重大灾害类型差异明显, 但整 个流域地质、地貌、气候作用相互关联，流域重大灾 害过程相互联动.

因此, 基于地球系统科学理念, 需要将地质地表过 程研究从“贯不通、联不上”的孤立状态转向“上中下 游联动、多过程互馈”的系统研究转变, 进一步厘清黄 河流域地质、地表、气候耦合过程与重大灾害时空分 布的响应时序，在黄河流域耦合孕灾机制与灾害联动 理论上实现原始突破.

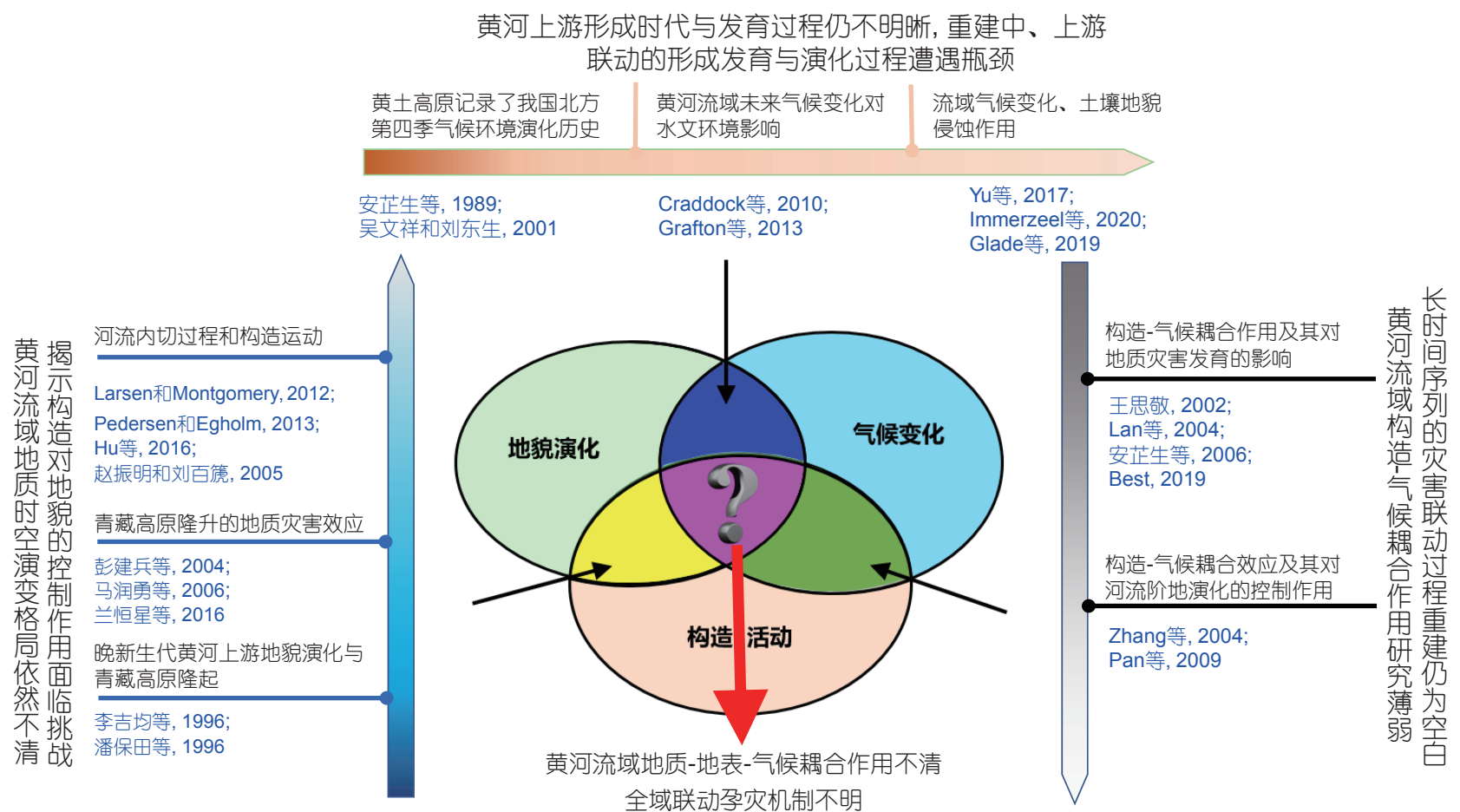

图 2 黄河流域地质地表过程及致灾机制研究脉络 


\section{2 探索黄河流域重大灾害链生与生态互馈效应}

黄河流域重大灾害本质上是复杂的地球内外动力 共同作用下的结果. 重大灾害动力学过程与生态环境 互馈影响, 地质安全与生态安全平衡又影响着人地协 调关系，一直是学界探讨的前沿问题. 尤其黄河流域 生态环境脆弱, 流域重大灾害与生态互馈效应显著. 黄河流域重大灾害研究脉络的梳理(图3 5)表明，在黄 河流域重大灾害的孕育历史、动力学过程、致灾效应 研究中，如何突破重大灾害链生与生态互馈效应是未 来亟需攻克的前沿方向.

黄河流域重大灾害孕育历史、动力学过程、致灾 效应具有特殊性：黄河流域上游具有复杂的构造-地 震-气候-河流侵蚀耦合孕灾背景，亟需揭示巨型滑坡 形成机理与灾害链演化, 进而提出巨型滑坡-堰塞湖溃 决灾害链评价方法体系，建立巨型滑坡复活与生态地 质安全防控理论. 黄河流域中游黄土水土灾害群发、 链生效应明显，亟需对黄土崩滑流群发的区域激发响 应机制及不同时空尺度的黄土灾害链风险模式展开深 入研究，建立黄河流域中游黄土水土灾害与生态系统 互馈平衡理论及评价体系. 黄河流域下游冲淤变化剧 烈、河岸易侵蚀坡塌、主流游荡多变, 已形成了游荡 河、滚河及悬河等特殊结构，加之雨带北移带来的强
降雨风险，亟需阐明复杂环境下巨型洪灾发生规律及 链生放大效应，提出黄河下游巨型洪灾情景模拟与生 态安全风险应对策略.

因此, 如何深入认知黄河流域复杂地表过程与重 大灾害的响应关系，揭示黄河流域重大灾害与生态系 统之间复杂的互馈关系，是保证地质安全与生态安全 平衡的前提, 也是未来研究发展趋势.

\section{3 建立黄河流域巨灾风险综合防范体系}

在当前全球变化、人地关系日益紧张的背景下， 地球系统科学成为当今地学领域最前沿的学科方向, 而实现人地协调发展成为可持续与高质量发展的核心 目标. 黄河流域重大灾害系统间存在复杂的交互联动 关系，同时黄河流域生态环境脆弱、人地关系紧张， 加大了重大灾害的危害程度与风险管理难度. 如何在 重大灾害风险防控的同时，协调人灾关系、缓解甚至 消除人地矛盾、实现地质安全与生态安全，保障人地 协调发展, 成为研究热点.

黄河流域重大灾害风险研究脉络的梳理(图6)表 明, 在当今信息技术快速发展更新的时代, 地球系统科 学思维、人地协调发展理念、大数据与智能技术，应 贯穿黄河流域重大灾害风险研究中。建立黄河流域多

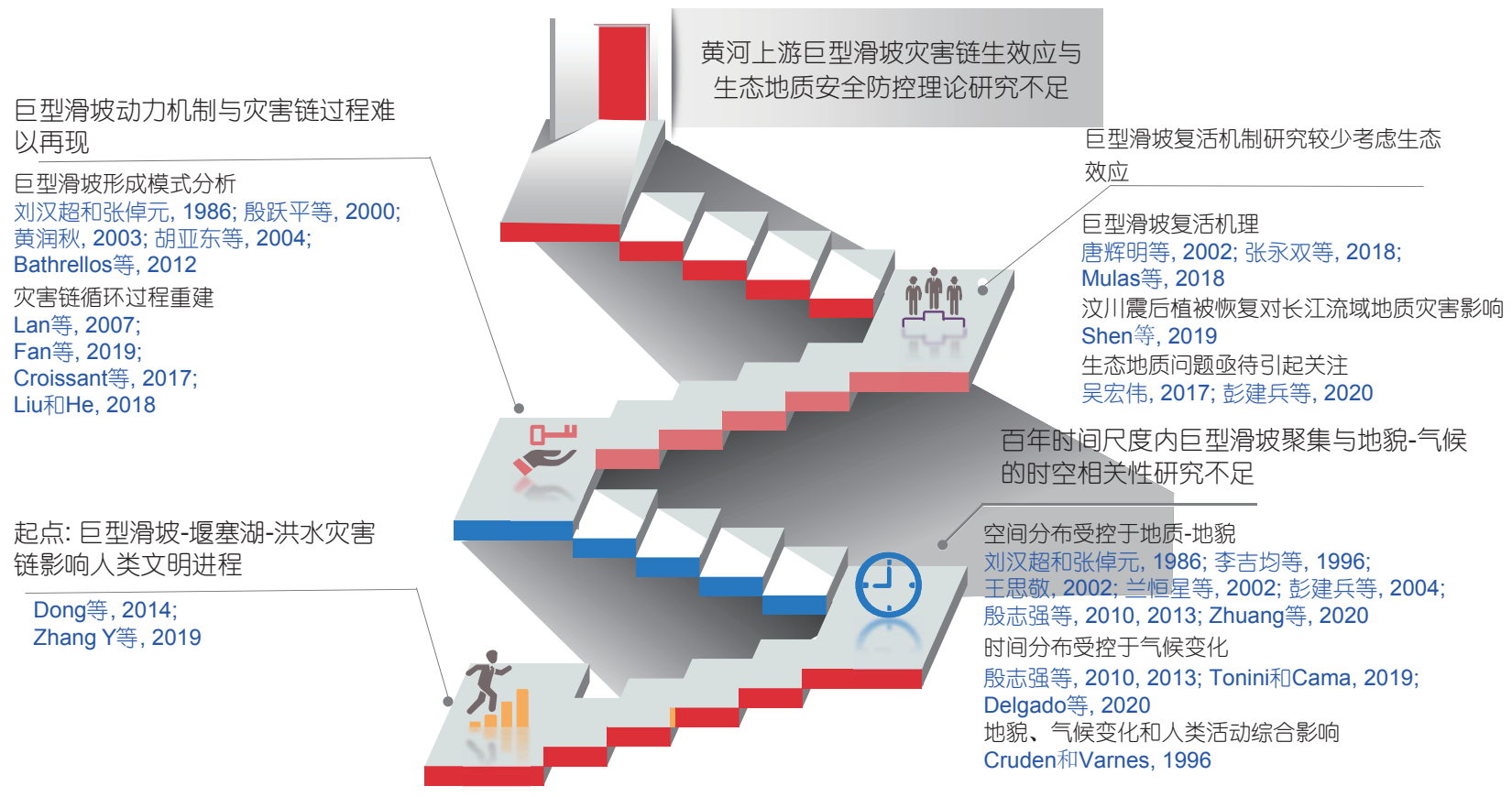

图 3 黄河流域上游巨型滑坡研究脉络 
黄河中游水土灾害与生态系统互馈研究亟需开展

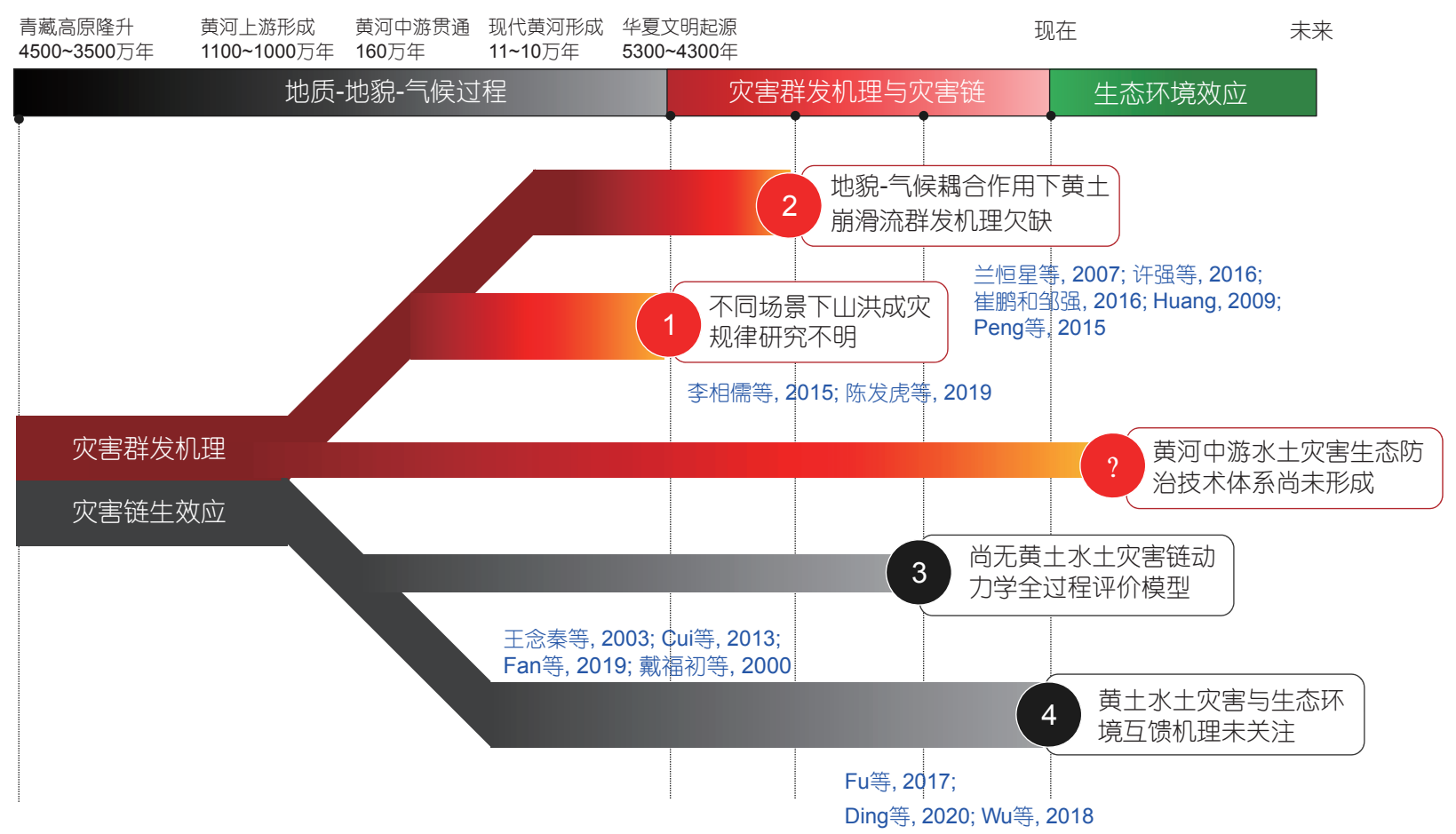

图 4 黄河流域中游水土灾害研究脉络

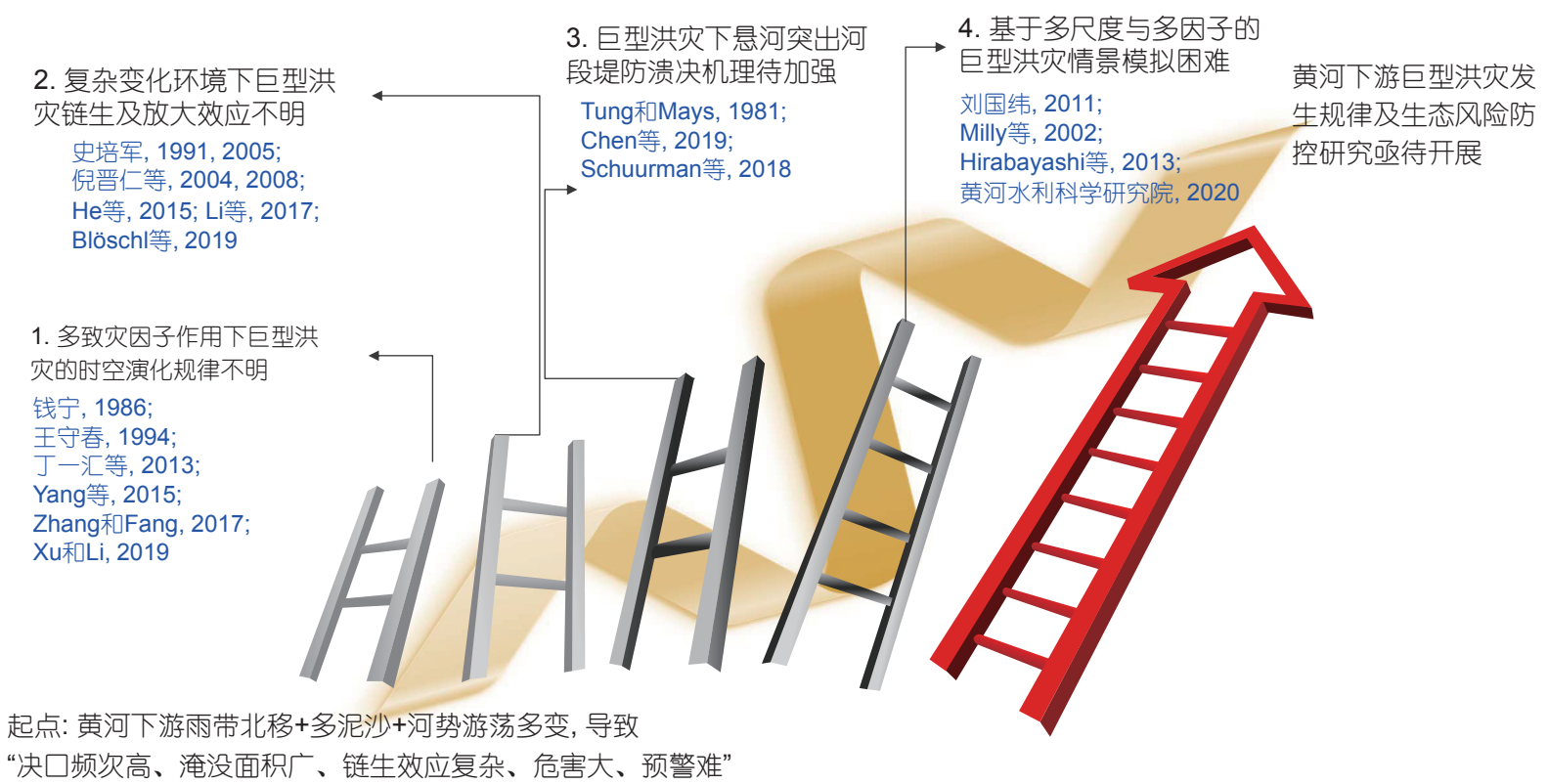

图 5 黄河流域下游巨型洪水研究脉络

区域、多灾种、多主体联动的巨灾综合风险评估模 型，构建人地协调的黄河流域巨灾综合风险防范理论
方法技术体系，研发基于大数据的巨灾风险防范智能 平台, 是重大灾害风险领域研究的前沿趋势. 


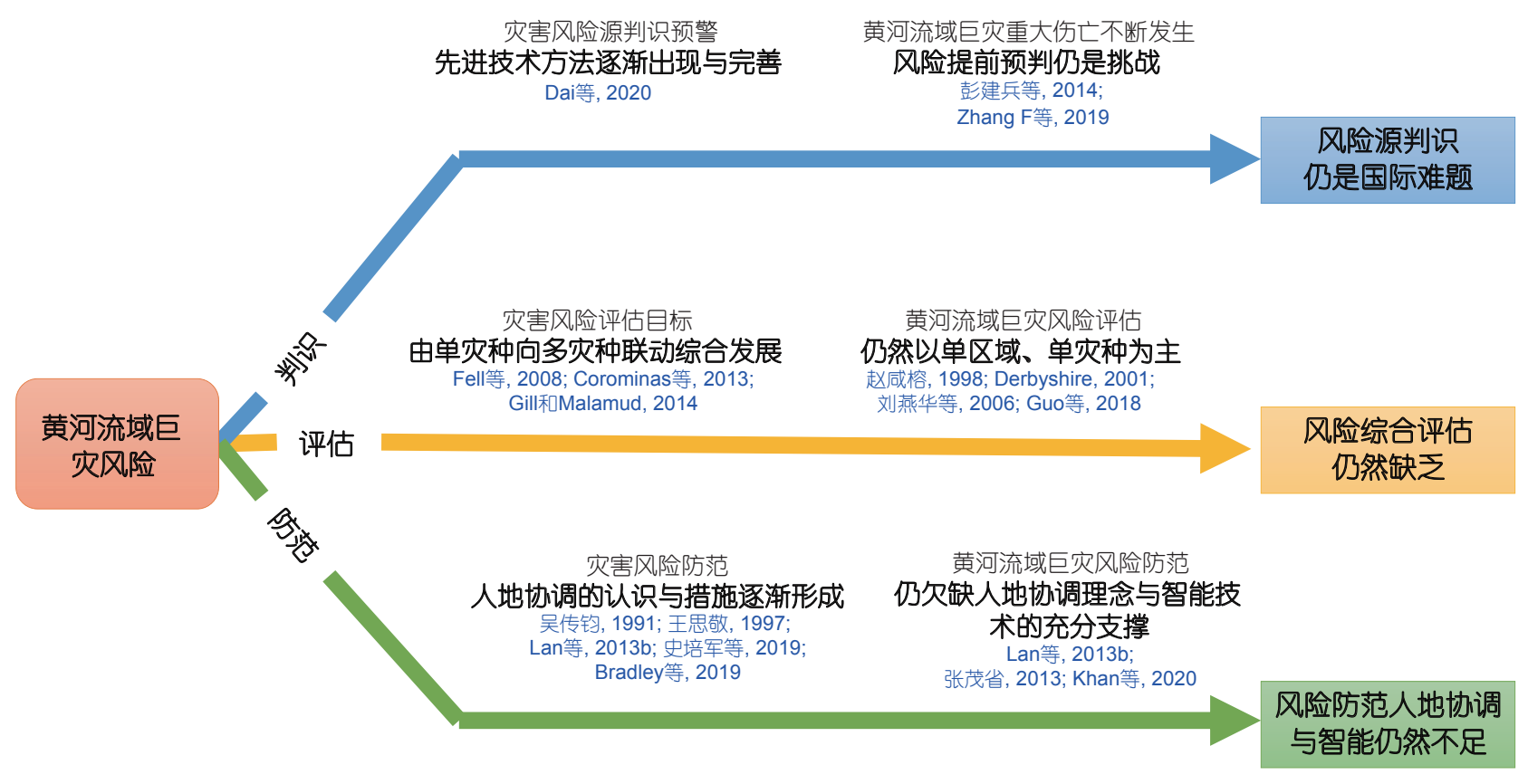

图 6 黄河流域重大灾害风险研究脉络

\section{4 黄河流域地质地表过程与重大灾害效应 研究的关键科学问题}

纵观黄河流域地质地表过程与重大灾害效应研究 国内外研究现状及发展趋势，目前有以下三个有待突 破的关键问题(图7).

\section{1 黄河流域地质-地表-气候过程耦合联动孕育巨 灾机制}

黄河流域地质、地表、气候过程与重大灾害响应 关系面临“时序重建困难”与“联动机制不清”的问题. 因此，如何揭示地质、地表与气候过程及其耦合联动 孕育巨灾机制，是当前黄河流域孕灾机制研究需首要 突破的关键科学问题.

如何重建多时空尺度中上游地质-地表-气候的演 变过程? 如何构建长时间尺度地质灾害数据库并分析 地质灾害与上述演变过程的关系? 如何准确建立黄河 下游决口、改道地质和历史记录? 如何打破孕灾机制 “分段分要素”孤立研究的局面,揭示地质-地表-气候过 程耦合作用下的黄河上、中、下游联动孕灾机制? 是 突破地质-地表-气候过程耦合联动孕育巨灾机制这一 关键科学问题所需首先解决的前沿科学问题.
为此, 需要明晰地质过程(百万年计)-地表过程(十 万年计)-气候过程(万年计), 梳理流域构造隆升与新构 造运动的时空演变过程, 认清其对地貌的控制作用; 重 建黄河中上游形成发育历史与地貌演化过程; 建立河 流发育与重大灾害时空分布的对应关系; 同时提升地 质灾害空间分布差异性的解译方法和技术水平，并基 于过程联动思路建立上中下游之间有效物质交换联 系. 才能在地质-地表-气候过程耦合联动孕灾机制上 取得理论性突破.

\section{2 地球动力系统跨尺度作用下重大灾害链生与 生态互馈效应}

黄河流域重大灾害效应显著，上游巨型滑坡、中 游黄土水土灾害、下游巨型洪灾研究面临成因机制研 究不系统、灾害链动力学过程与生态互馈效应难以准 确评价的问题. 因此, 如何从致灾效应角度揭示重大灾 害链动力学过程并进行致灾效应评价, 如何从地质安 全与生态安全角度建立重大灾害与生态互馈理论, 是 黄河流域重大灾害效应研究亟需突破的关键科学 问题.

如何将地球系统科学思维及理念, 贯穿到黄河流 域重大灾害的孕育历史、动力学过程、致灾效应研究 


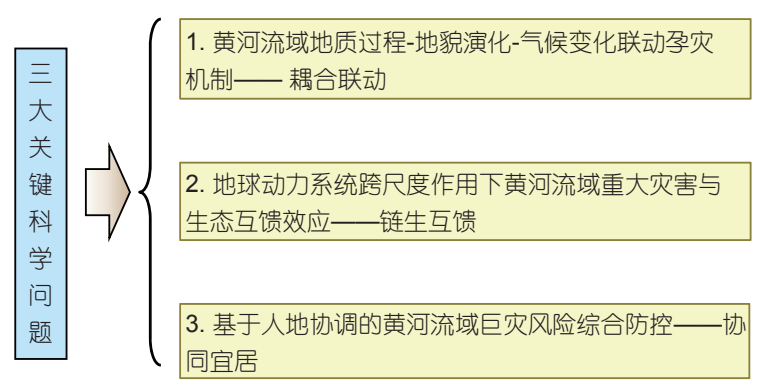

图 7 有待突破的关键科学问题

中，揭示黄河流域上游巨型滑坡、中游水土灾害、下 游巨型洪灾的害动力学机制、灾害链生与生态互馈效 应，是突破当前黄河流域重大灾害效应研究的关键科 学问题所需首要解决的前沿科学问题.

为解决黄河上游巨型滑坡灾害与生态地质环境互 馈效应关键科学问题, 需要首先厘清构造-地震-气候河流侵蚀耦合作用下黄河上游巨型滑坡形成机制，从 致灾角度揭示巨型滑坡灾害链动力学过程与致灾放大 效应; 其次需要提出巨型滑坡-堰塞湖溃决灾害链评价 方法体系，从重大灾害与生态安全角度建立巨型滑坡 复活与生态地质安全互馈理论与方法.

为解决黄河中游黄土水土灾害群发与生态互馈效 应关键科学问题, 需要首先阐明黄河中游地质环境-气 候耦合作用下黄土崩滑流群发响应机制、灾害群发与 河流动力互馈过程, 探明黄土水土灾害链动力学过程, 实现不同时空尺度的黄土水土灾害链生效应判识; 其 次需要构建水土灾害与生态环境互馈效应评价体系, 并提出生态工程防灾减灾理论与方法.

为解决黄河下游巨型洪灾发生规律及放大效应的 关键科学问题, 需要首先提出气候变化和人类活动耦 合作用下黄河下游巨型洪灾的时空演变规律和链生放 大效应, 揭示突破洪水灾害与生态功能互馈机制; 其次 揭示河势游荡及悬河特殊结构下巨型洪灾形成的机 理、动力学过程，并提出黄河下游巨型洪灾情景及风 险应对策略.

\section{3 基于人地协调的黄河流域重大灾害风险综合 防控体系}

黄河流域重大灾害风险面临“源辨不准、量化不 足”“灾害数据离散、集成度低、巨灾风险防范智能化 低”等问题. 因此，如何提出黄河流域重大灾害风险综
合评估技术，建立基于人地协调的流域重大灾害风险 防范理论技术体系，是黄河流域重大灾害综合风险智 能防范有待突破的关键科学问题.

如何利用地球系统科学思维、人地协调发展理 念、大数据与智能技术，开展黄河流域重大灾害风险 研究, 突破黄河流域多区域、多灾种、多主体联动综 合风险评估难点，构建基于人地协调理念的巨灾风险 防范理论方法技术体系，研发巨灾风险防范智能平台， 是突破当前黄河流域重大灾害风险综合防控体系这一 关键科学问题所需首先解决的前沿科学问题.

要解决黄河流域灾害风险源“辨识不准、量化不 足”, 灾害数据离散、集成度低、灾害风险防范辅助决 策智能化低等问题, 首先需要突破黄河流域重大灾害 大数据的深度融合与集成难点，开展全面而精准的巨 灾风险源辨识，实现基于过程和机理的地球系统巨灾 综合模拟及精细化预估，进而刻画“低频高损”的巨灾 风险; 其次要厘清巨灾风险与人地时空演化关系, 突 破支撑应急管控智能决策的大数据集成与共享服务技 术瓶颈，构建基于人地协调的智能巨灾防范的理论方 法体系.

\section{5 黄河流域地质地表过程与重大灾害效应 研究展望}

\section{1 黄河流域重大灾害效应研究建议方向}

面向“黄河流域生态保护和高质量发展”重大国家 战略需求, 针对黄河流域面临的重大灾害风险与生态 安全问题, 需要从流域系统的整体性出发, 系统开展 黄河流域地质地表过程与重大灾害效应研究. 研究过 程需注重地球圈层相互作用、聚焦重大灾害效应、保 障地质与生态安全、促进人地协调(图8). 进而, 厘清 一条黄河串起的三大链条: “地质、地表与气候的链 接关系、重大灾害与生态环境的互馈关系、流域风险 与人地安全的协同关系”, 为黄河流域生态保护和高质 量发展提供科学依据.

黄河流域重大灾害效应研究需“重建地质地表与 气候孕灾过程、聚焦重大灾害现在效应、展望重大灾 害未来风险”, 具体需要开展黄河流域地质、地表和气 候过程及其孕灾背景与模式研究; 揭示黄河流域上游 巨型滑坡形成机理及灾害链演化机制; 诠释黄河流域 中游黄土地区水土灾害机制与灾害链生效应; 阐明黄 
河流域下游巨型洪灾发生规律及链生放大效应; 预测 黄河流域重大灾害风险，提出黄河流域灾害风险防范 的理论和方法体系(图9).

\section{2 黄河流域重大灾害效应研究建议思路}

黄河流域穿越不同地质地貌单元，承受复杂的多
圈层相互作用, 历经地质地表过程与人类活动过程互 馈影响，其地质过程的独特性、地貌过程的典型性、 气候过程的多变性和人类活动的强干扰性, 以及重大 灾害的高风险性，决定了黄河流域重大灾效应研究具 有地球系统科学属性. 因此, 针对黄河流域地质地表过 程与重大灾害效应的研究, 需要多学科交叉, 突破流域

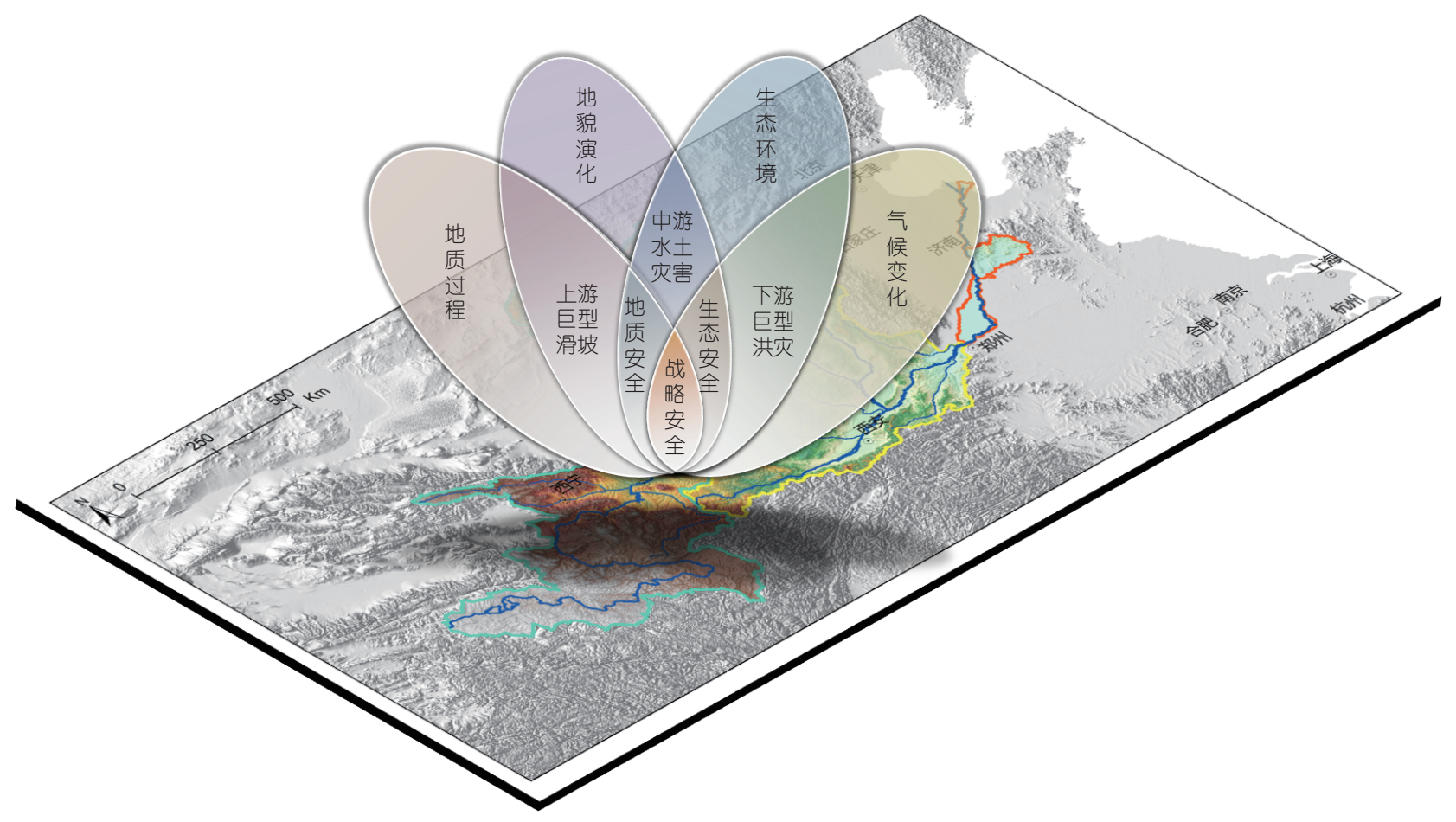

图 8 黄河流域重大灾害研究的科学内涵

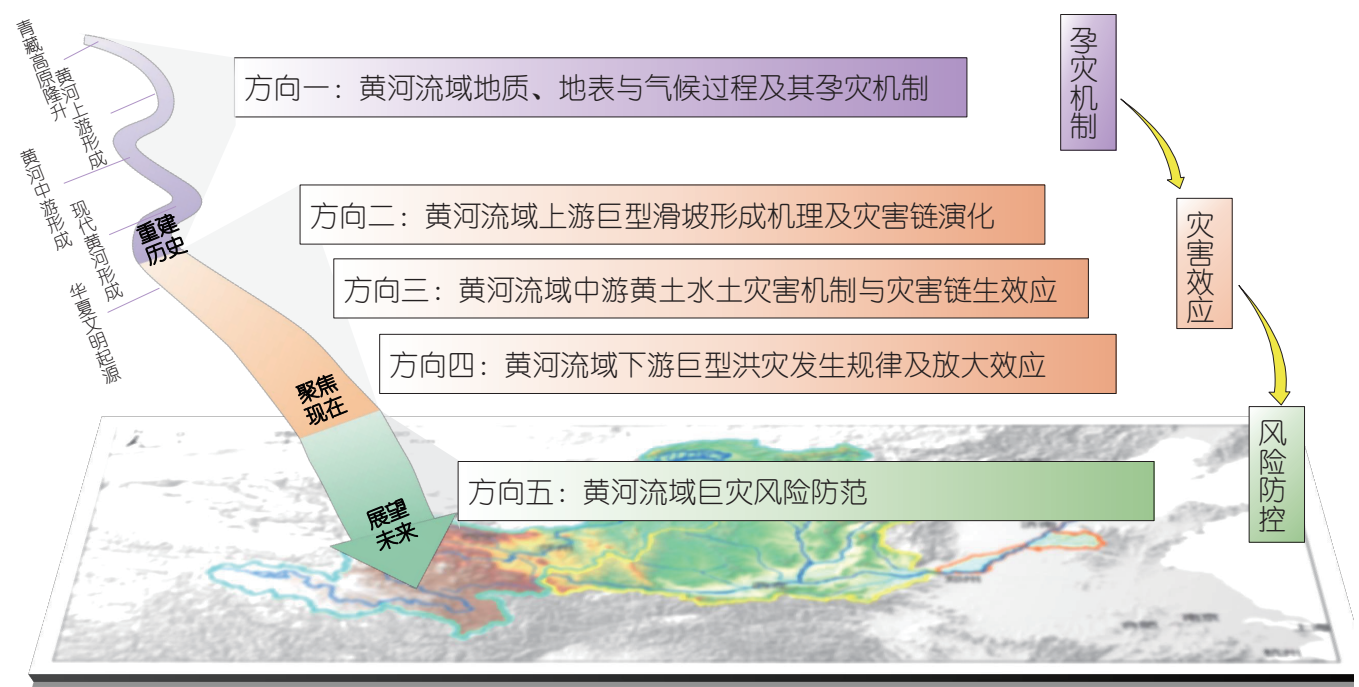

图 9 黄河流域重大灾害效应研究建议方向 
“上中下游联动、多过程互馈”难题, 从“重建历史-聚焦 现代-展望未来”的时间轴尺度揭示黄河流域地质、地 表与气候联动孕灾机制; 需要创新理论体系, 从“地-域河”的空间轴尺度阐明黄河流域重大灾害区域模式、 动力学机制、灾害链生与生态互馈效应; 需要突破技 术瓶颈，从“人地协调观”角度建立黄河流域综合风险 评估模型与防控理论, 保障流域地质与生态安全, 为黄 河流域生态保护和高质量发展提供科学依据(图10).

\section{3 黄河流域重大灾害综合风险防控应用示范格局}

黄河流域地质地表过程与重大灾害效应研究需注
重地球圈层相互作用、聚焦重大灾害效应、保障地质 与生态安全、促进人地协调, 从理论、技术与应用层 次厘清地质、地表与气候的链接关系、重大灾害与生 态环境的互馈关系、流域风险与人地安全的协同关 系. 为此, 首先要全面揭示黄河流域上游巨型滑坡形成 机理及灾害链演化，诠释黄河流域中游黄土地区水土 灾害机制与灾害链生效应，阐明黄河流域下游巨型洪 灾发生规律及链生放大效应，实现重大灾害研究全流 域覆盖; 其次，要基于黄河流域“地貌控灾易发区、构 造控灾易发区”的重大灾害分布与演化规律, 建立研究 基地及观测台站, 开展重大风险多源动态立体监测, 基

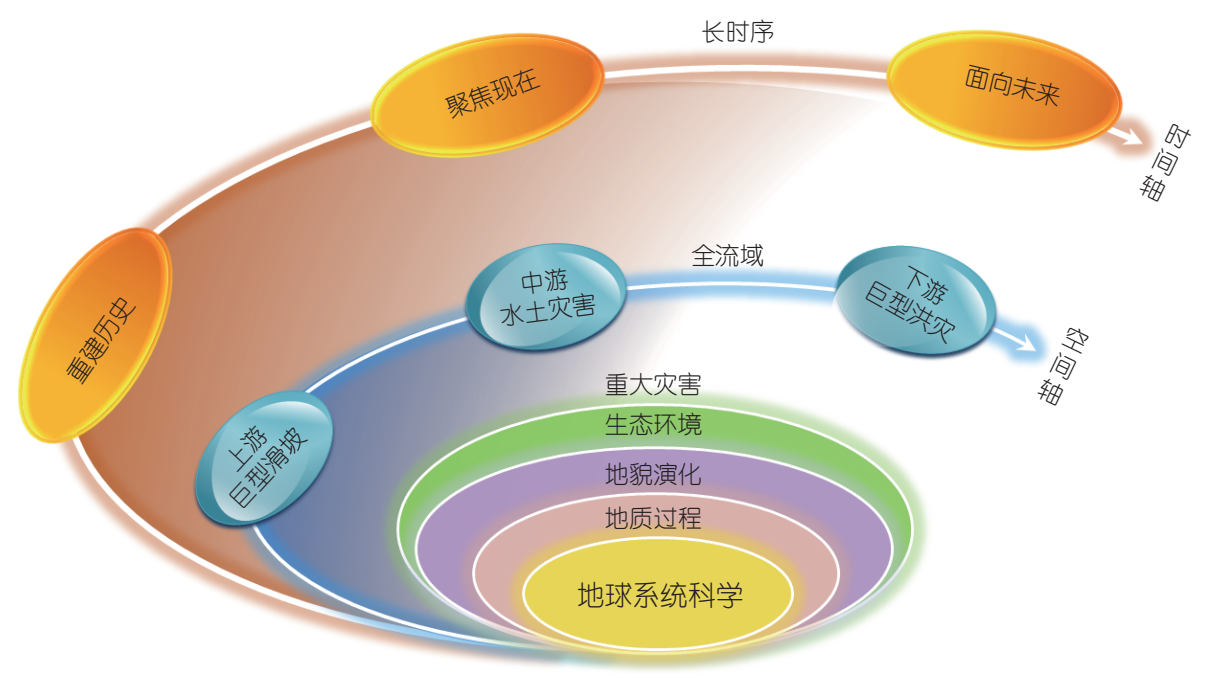

图 10 基于地球系统科学思想的黄河流域重大灾害效应研究思路

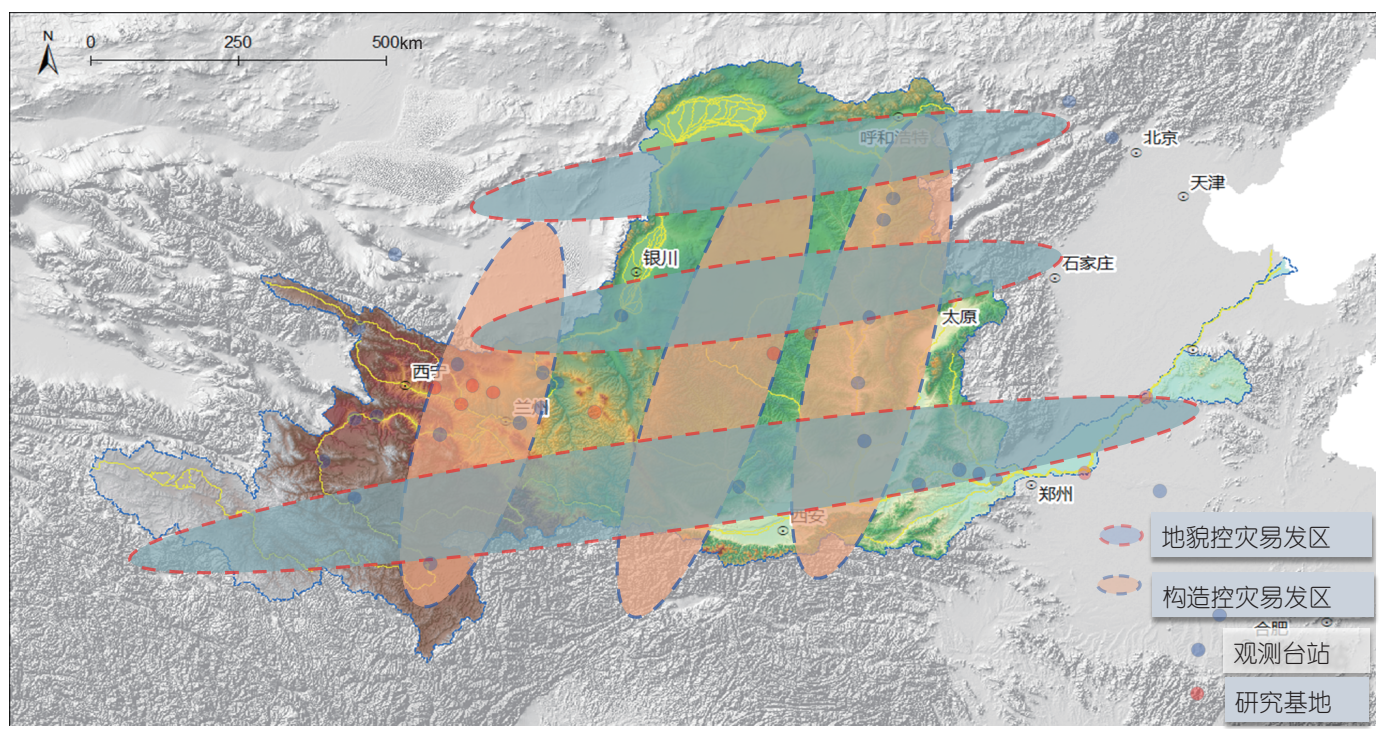

图 11 黄河流域重大灾害综合风险“三横三纵”管控格局规划 
于多源灾害风险数据深度融合方法，构建重大风险综 合评估模型，开展黄河流域重大灾害综合风险评估， 形成黄河流域重大灾害综合风险“三横三纵”管控应用 示范格局(图11), 为实现黄河流域生态保护和高质量 发展提供科技支撑.

\section{参考文献}

安芷生, Kukla G, 刘东生. 1989. 洛川黄土地层学. 第四纪研究, 9: $155-168$

安芷生, 张培震, 王二七, 王苏民, 强小科, 李力, 宋友桂, 常宏, 刘晓 东, 周卫健, 刘卫国, 曹军䩀, 李小强, 沈吉, 刘禹, 艾莉. 2006. 中新 世以来我国季风-干旱环境演化与青藏高原的生长. 第四纪研究, 26: 678-693

蔡俊超. 2014. 库水抬升作用下岸坡倾倒变形机理与演化发展过程 研究. 硕士学位论文. 成都: 成都理工大学

陈发虎, 傅伯杰, 夏军, 吴铎, 吴绍洪, 张镱锂, 孙航, 刘禹, 方小敏, 秦 伯强, 李新, 张廷军, 刘宝元, 董治宝, 侯书贵, 田立德, 徐柏青, 董 广辉, 郑景云, 杨威, 王金金, 李再军, 王飞, 胡振波, 王杰, 刘建宝, 陈 建徽, 黄伟, 侯居峙, 蔡秋芳, 隆浩, 姜明, 胡亚鲜, 冯晓明, 莫兴国, 杨晓燕, 张东菊, 王秀红, 尹云鹤, 刘晓晨. 2019. 近70年来中国自 然地理与生存环境基础研究的重要进展与展望. 中国科学: 地球 科学, 49: 1659-1696

陈天慧，田耀. 2017. 美国防洪治理的策略演变及启示: 以密西西比 河洪水治理为例. 中国水利, 13: 51-53

程钥, 尹建中, 王建事. 2019. 黄河三角洲地区自然资本动态演变与 影响因素研究. 中国人口资源与环境, 29: 127-136

崔鹏, 邹强. 2016. 山洪泥石流风险评估与风险管理理论与方法. 地 理科学进展, 35: 137-147

戴福初, 陈守义, 李焯芬. 2000. 从土的应力应变特性探讨滑坡发生 机理. 岩土工程学报, 22: 127-130

丁一汇, 孙颖, 刘芸芸, 司东, 王遵娅, 朱玉祥, 柳艳菊, 宋亚芳, 张锦. 2013. 亚洲夏季风的年际和年代际变化及其未来预测. 大气科学, 37: $253-280$

郭小花. 2017. 龙羊峡-刘家峡河段巨型滑坡堵河事件与黄河演化之 间的关系. 博士学位论文. 西安: 长安大学

郭正堂, 丁仲礼, 刘东生. 1996. 黄土中的沉积-成壤事件与第四纪气 候旋回. 科学通报, 41: 56-59

胡贵明, 黄春长, 周亚利, 庞奖励, 查小春, 郭永强, 张玉柱, 赵雪如. 2015. 伊河龙门峡段全新世古洪水和历史洪水水文学重建. 地理 学报, 70: 1165-1176

胡江春, 郭福伟, 王红芳, 张金水, 杨成林. 2018. 滑坡体变形运动的 多层次监测研究. 人民黄河, 40: 116-119

胡亚东, 傅荣华, 夏克勤. 2004. 黄河积石峡水电站库区泥石流危险 度评价. 灾害学, 19: 36-41
黄河水利委员会. 1959 . 人民黄河. 北京: 水利电力出版社

黄河水利科学研究院. 2020. 2020年洪水预演实体模型试验. 郑州: 黄河水利科学研究院

黄润秋. 2003. 中国西部地区典型岩质滑坡机理研究. 第四纪研究, 23: $640-647$

姜程, 霍艾迪, 朱兴华, 韦红, 郑小路, 王小帆. 2019. 黄土水力侵蚀-滑 坡-泥流灾害链的研究现状. 自然灾害报, 28: 38-43

兰恒星, 伍法权. 2000. 基于条分法的滑坡位移非线性动力学模拟方 法. 工程地质学报, 8: 374-378

兰恒星, 伍法权, 周成虎, 王思敬. 2002. 基于GIS的云南小江流域滑 坡因子敏感性分析. 岩石力学与工程学报, 21: 1500-1506 兰恒星, 肖锐针, 严福章, 伍宇明. 2016. 川藏联网工程地质条件分析. 工程地质学报, 24: 375-385

兰恒星, 伅义星, 伍宇明. 2019. 岩体结构效应与长远程滑坡动力学. 工程地质学报, 27: 108-122

兰恒星, 周成虎, 伍法权, 王苓涓. 2003. GIS支持下的降雨型滑坡危 险性空间分析预测. 科学通报, 48: 507-512

兰恒星，周成虎，高星，程维明，王治华，杨志华，李郎平，伍宇明. 2013. 四川雅安芦山地震灾区次生地质灾害评估及对策建议. 地 理科学进展, 32: 499-504

兰恒星, 周成虎, 王小波. 2007. 泥石流本构模型及动力学模拟研究 现状综述. 工程地质学报, 15: 314-321

李军华, 江恩慧, 曹永涛. 2018a. “82.8”典型千年一遇设计洪水黄河 下游演进模拟试验. 技术报告. 郑州: 黄河水利科学研究院 李军华, 江恩慧, 董其华, 张向萍, 许琳娟. 2018b. 黄河下游均衡输沙 与游荡性河道整治. 技术报告. 郑州: 黄河水利出版社

李军华, 江恩慧, 夏修杰. 2019. “77.8”高含沙洪水黄河下游演进模拟 试验. 技术报告. 郑州: 黄河水利科学研究院

李军华, 江恩慧, 夏修杰. 2020. 1761年超标准洪水黄河下游演进模 拟试验. 技术报告. 郑州: 黄河水利科学研究院

李吉均, 方小敏, 马海洲, 朱俊杰, 潘保田, 陈怀录. 1996. 晚新生代黄 河上游地貌演化与青藏高原隆升. 中国科学 $\mathrm{D}$ 辑: 地球科学, 26 : $316-322$

李小建, 文玉钊, 李元征, 杨慧敏. 2020. 黄河流域高质量发展: 人地 协调与空间协调. 经济地理, 40: 1-10

李小林, 郭小花, 李万花. 2011. 黄河上游龙羊峡-刘家峡河段巨型滑 坡形成机理分析. 工程地质学报, 19: 516-529

李相儒, 金钊, 张信宝, 周卫健. 2015. 黄土高原近60年生态治理分析 及未来发展建议. 地球环境学报, 6: 248-254

刘高峰, 龚艳冰, 王慧敏, 赖小芗. 2019. 国外堤防风险管理现状及对 我国的启示. 长江科学院院报, 36: 53-58

刘国纬. 2011. 黄河下游治理的地学基础. 中国科学: 地球科学, 41: $1511-1523$

刘汉超, 黎力, 吴本轩, 姚红庆. 1990. 某地区滑坡复活的模式、机制 和条件. 地质灾害与环境保护, 1: 37-45

刘汉超, 张倬元. 1986. 龙羊峡附近超固结粘土大型滑坡的形成机理 
及高速远滑的原因. 成都地质学院学报, 13: 94-104

刘晓, 唐辉明, 胡新丽, 王亮清, 廖少波, 邹宗兴. 2012. 金鼓高速远程 滑坡形成机制及动力稳定性. 岩石力学与工程学报，31：25272537

刘燕华, 康相武, 吴绍洪, 杨勤业, 戴尔阜. 2006. 消减黄河下游洪灾 风险研究. 科学通报, 51: 129-139

刘燕华, 康相武, 吴绍洪. 2008. 黄河下游洪水灾害风险与后备流路. 北京: 科学出版社

刘艺, 张辉, 邓青. 2018. 大数据背景下的智慧安全应急管理创新若 干关键科学问题. 现代管理科学, (10): 94-96

马润勇, 彭建兵, 刘利年, 潘爱芳. 2006. 青藏高原隆升的气候环境效 应与黄土高原构造侵蚀. 水土保持研究, 13: 220-225

马晓忠, 彭雪辉, 张友明, 杨德玮, 盛金保. 2015. 基于单元堤段洪泽 湖大堤风险分析. 水利水电技术, 46: 143-147

马柱国, 符淙斌, 周天军, 严中伟, 李明星. 2020. 黄河流域气候与水 文变化的现状及思考. 中国科学院院刊, 35: 52-60

倪晋仁, 李秀霞, 薛安, 李英奎, 韩鹏, 李天宏, 刘仁志. 2004. 泥沙灾 害链及其在灾害过程规律研究中的应用. 自然灾害学报, 13: 1-9 倪晋仁, 王兆印, 王光谦. 2008. 江河泥沙灾害形成机理及其防治. 北 京: 科学出版社

钮仲勋. 1993. 黄河流域环境演变与水沙运行规律研究文集(第四 集). 北京: 地质出版社

潘保田, 李吉均, 曹继秀, 陈发虎. 1996. 化隆盆地地貌演化与黄河发 育研究. 山地研究, 14: 153-158

裴向军, 崔圣华, 黄润秋. 2018. 大光包滑坡启动机制: 强震过程滑带 动力扩容与水击效应. 岩石力学与工程学报, 37: 430-448

彭建兵. 1997. 黄河积石峡水电站水库滑坡工程地质研究. 西安: 陕 西科学技术出版社

彭建兵, 兰恒星, 钱会, 王文科, 李荣西, 李振洪, 庄建琦, 刘釒, 刘世 杰. 2020. 宜居黄河科学构想. 工程地质学报, 28: 189-201

彭建兵, 林鸿州, 王启耀, 庄建琦, 成玉祥, 朱兴华. 2014. 黄土地质灾 害研究中的关键问题与创新思路. 工程地质学报, 22: 684-691

彭建兵, 马润勇, 卢全中, 李喜安, 邵铁全. 2004. 青藏高原隆升的地 质灾害效应. 地球科学进展, 19: 457-466

彭建兵, 吴迪, 段钊, 唐东旗, 成玉祥, 车文越, 黄伟亮, 王启耀, 庄建 琦. 2016. 典型人类工程活动诱发黄土滑坡灾害特征与致灾机理. 西南交通大学学报, 51: 971-980

彭政奎, 杨东强. 2019. 海原地震典型黄土滑坡群形成机制与运动特 征研究. 成都大学学报(自然科学版), 38: 447-450

钱宁. 1986. 1855 年铜瓦厢决口以后黄河下游历史演变过程中的若 干问题. 人民黄河, 5: 66-72

郡明安, 上官周平. 2000. 控制水土流失促进黄土高原生态环境建设. 中国基础科学, 6: 47-51

沈怡, 赵世暹, 郑道隆. 1935. 黄河年表. 北京: 原军事委员会资源委 员会

史培军. 1991. 灾害研究的理论与实践. 南京大学学报, 11: 37-42
史培军. 2005. 四论灾害系统研究的理论与实践. 自然灾害学报, 14: $1-7$

史培军. 2009. 五论灾害系统研究的理论与实践. 自然灾害学报, 18: $1-9$

史培军, 宋长青, 程昌秀. 2019. 地理协同论一从从理解“人-地关系” 到设计“人-地协同”. 地理学报, 74: 3-15

苏人琼, 杨勤业. 1996. 黄河流域灾害环境综合治理对策. 人民黄河, 18: $16-20,38$

孙延贵, 方洪宾, 张琨, 赵福岳, 刘世英. 2007. 共和盆地层状地貌系 统与青藏高原隆升及黄河发育. 中国地质, 34: 1141-1147

唐辉明, 马淑芝, 刘佑荣, 贾洪彪. 2002. 三峡工程库区巴东县赵树岭 滑坡稳定性与防治对策研究. 地球科学, 27: 621-625

唐亚明，张茂省，薛强. 2011。一种大比例尺的滑坡风险区划方法 一以延安市区黄土滑坡风险评价为例. 地质通报, 30: 166-172

王开拓. 2018. 土石防洪堤运行中的工程风险与处置方法. 中国水能 及电气化, 3: 23-26

王家鼎, 惠泱河. 2002. 黄土地区灌溉水诱发滑坡群的研究. 地理科 学, 22: 305-310

王念秦, 张倬元, 王家鼎. 2003. 一种典型黄土滑坡的滑距预测方法. 西北大学学报(自然科学版), 33: 111-114

王守春. 1994. 黄河下游1566年后和1875后决溢时空变化研究. 人民 黄河, 17: 53-58

王思敬. 1997. 论人类工程活动与地质环境的相互作用及其环境效 应. 地质灾害与环境保护, 8: 20-27

王思敬. 2002. 地球内外动力耦合作用与重大地质灾害的成因初探. 工程地质学报, 10: 115-117

王涌泉. 2007. 1855年黄河大改道与百年灾害链. 地学前缘, 14: 6-11 魏刚. 2013. 黄河上游龙羊峡至寺沟峡段巨型滑坡分布特征及风险 评价研究. 硕士学位论文. 北京: 中国地质大学(北京)

魏占胥, 马文礼, 肖建兵, 殷志强, 魏刚. 2017. 黄河上游松坝峡特大 型滑坡堰塞湖及地貌效应研究. 中国地质灾害与防治学报, 28 : $16-23$

武彩霞, 许领, 戴福初, 闵弘, 谭国焕, 广国麟, 周跃峰. 2011. 黑方台 黄土泥流滑坡及发生机制研究. 岩土力学, 32: 1767-1773

吴传钧. 1991. 论地理学的研究核心一人地关系地域系. 经济地理, 11: $1-6$

吴宏伟. 2017. 大气-植被-土体相互作用: 理论与机理. 岩土工程学 报, 39: 1-47

吴文祥, 刘东生. 2001. 气候转型与早期人类迁徙. 海洋地质与第四 纪地质, 21: 103-109

夏军, 石卫. 2016. 变化环境下中国水安全问题研究与展望. 水利学 报, 47: 292-301

徐福龄. 1979. 黄河下游明清时代河道和现行河道演变的对比研究. 人民黄河, (1): 66-76

许强, 彭大雷, 元星, 董秀军, 李骅锦, 巨袁臻. 2016. 2015年4.29甘肃 黑方台党川2\#滑坡基本特征与成因机理研究. 工程地质学报, 24: 
$167-180$

易庆林, 张明玉, 文凯, 徐金金, 尚敏. 2017. 三峡库区白水河滑坡变形 特征及影响因素的阶段分析. 三峡大学学报(自然科学版), 39: $38-42$

殷跃平, 张加桂, 陈宝荪, 康宏达. 2000. 三峡库区巫山移民新城址松 散堆积体成因机制研究. 工程地质学报, 8: 265-271

殷志强, 程国明, 胡贵寿, 魏刚, 王运青. 2010. 晚更新世以来黄河上 游巨型滑坡特征及形成机理初步研究. 工程地质学报, 18: 41-51 殷志强, 秦小光, 赵无忌, 李小林, 程国明, 魏刚, 史立群, 袁材栋 2016. 黄河上游滑坡泥石流时空演化及触发机制. 北京: 科学出 版社

殷志强, 魏刚, 祁小博, 周翠琼. 2013. 黄河上游寺沟峡-拉干峡段滑坡 时空特征及对气候变化的响应研究. 工程地质学报, 21: 129-137

张春山, 李国俊, 张业成, 马寅生. 2006. 黄河上游地区崩塌滑坡泥石 流地质灾害风险评价. 地质力学学报, 12: 211-218

张含英. 1982. 历代治河方略探讨. 北京: 水利出版社

张金良, 刘生云, 李超群. 2018. 论黄河下游河道的生态安全屏障作 用. 人民黄河, 40: 21-24

张茂省. 2013. 引水灌区黄土地质灾害成因机制与防控技术一以 黄河三峡库区甘肃黑方台移民灌区为例. 地质通报, 32: 833-839

张茂省, 程秀娟, 董英, 于国强, 朱立峰, 裴赢. 2013. 冻结滞水效应及 其促滑机理一以甘肃黑方台地区为例. 地质通报, 32: 852-860 张培震, 邓起东, 张竹琪, 李海兵. 2013. 中国大陆的活动断裂、地震 灾害及其动力过程. 中国科学: 地球科学, 43: 1607-1620

张向萍, 李军华, 王远见, 江恩慧. 2019. 黄河下游宽滩区重大洪涝灾 害情景下的物理暴露量分析. 中国防汛抗旱, 29: 22-28

张向萍, 江恩慧, 李军华. 2020. 黄河下游宽滩区洪涝灾害物理暴露 量研究. 人民黄河, 42: 380-386

张永双, 吴瑞安, 郭长宝, 王立朝, 姚金金, 杨志华. 2018. 古滑坡复活问 题研究进展与展望. 地球科学进展, 33: 728-740

张玉柱, 黄春长, 周亚利, 庞奖励, 查小春, 周强, 郭永强, 陈莹璐, 郑 紫星, 胡迎, 胡贵明, 刘涛. 2017. 黄河上游积石峡史前滑坡堰塞 湖形成年代与发展演变研究. 中国科学：地球科学，47：13571370

赵无忌, 殷志强, 马吉福, 秦小光. 2016. 黄河上游贵德盆地席䓅滩巨 型滑坡发育特征及地貌演化. 地质论评, 62: 709-721

赵咸榕. 1998. 黄河流域洪水风险图的分析与制作. 人民黄河, (7): 35

赵振明, 刘百簏. 2005. 对龙羊峡形成的初步认识. 西北地质, 38: 24 31

周保, 彭建兵, 殷跃平, 李小林, 魏刚, 马小强. 2014. 黄河上游拉干峡寺沟峡段特大型滑坡及其成因研究. 地质论评, 60: 138-144

朱平一, 程尊兰, 游勇. 2000. 川藏公路培龙沟泥石流输砂堵江成因 探讨. 自然灾害学报, 9: 80-83

朱兴华, 彭建兵, 同霄, 马鹏辉. 2017. 黄土地区地质灾害链研究初探. 工程地质学报, 25: 117-122
邹逸麟. 2006. 历史时期黄河流域的环境变迁与城市兴衰. 江汉论坛, 5: 98-105

Anselmo V, Galeati G, Palmieri S, Rossi U, Todini E. 1996. Flood risk assessment using an integrated hydrological and hydraulic modelling approach: A case study. J Hydrol, 175: 533-554

Apel H, Thieken A H, Merz B, Blöschl G. 2004. Flood risk assessment and associated uncertainty. Nat Hazards Earth Syst Sci, 4: 295-308

Bathrellos G D, Gaki-Papanastassiou K, Skilodimou H D, Papanastassiou D, Chousianitis K G. 2012. Potential suitability for urban planning and industry development using natural hazard maps and geological-geomorphological parameters. Environ Earth Sci, 66: $537-548$

Bao Z, Zhang J, Wang G, Chen Q, Guan T, Yan X, Liu C, Liu J, Wang J. 2019. The impact of climate variability and land use/cover change on the water balance in the Middle Yellow River Basin, China. J Hydrol, 577: 123942

Best J. 2019. Anthropogenic stresses on the world's big rivers. Nat Geosci, 12: 7-21

Blöschl G, Hall J, Viglione A, Perdigão R A P, Parajka J, Merz B, Lun D, Arheimer B, Aronica G T, Bilibashi A, Boháč M, Bonacci O, Borga M, Čanjevac I, Castellarin A, Chirico G B, Claps P, Frolova N, Ganora D, Gorbachova L, Gül A, Hannaford J, Harrigan S, Kireeva M, Kiss A, Kjeldsen T R, Kohnová S, Koskela J J, Ledvinka O, Macdonald N, Mavrova-Guirguinova M, Mediero L, Merz R, Molnar P, Montanari A, Murphy C, Osuch M, Ovcharuk V, Radevski I, Salinas J L, Sauquet E, Šraj M, Szolgay J, Volpi E, Wilson D, Zaimi K, Živković N. 2019. Changing climate both increases and decreases European river floods. Nature, 573: 108111

Blum M, Pecha M. 2014. Mid-Cretaceous to Paleocene North American drainage reorganization from detrital zircons. Geology, 42: 607-610 Bradley K, Mallick R, Andikagumi H, Hubbard J, Meilianda E, Switzer A, Du N, Brocard G, Alfian D, Benazir B, Feng G, Yun S H, Majewski J, Wei S, Hill E M. 2019. Earthquake-triggered 2018 Palu Valley landslides enabled by wet rice cultivation. Nat Geosci, 12: 935-939

Chen Y Z, Overeem I, Kettner A J, Gao S, Syvitski J P M, Wang Y J. 2019. Quantifying sediment storage on the floodplains outside levees along the lower Yellow River during the years 1580-1849. Earth Surf Proc Land, 44: 581-594

Clift P D, Blusztajn J. 2005. Reorganization of the western Himalayan river system after five million years ago. Nature, 438: 1001-1003

Cook K L, Andermann C, Gimbert F, Adhikari B R, Hovius N. 2018. Glacial lake outburst floods as drivers of fluvial erosion in the Himalaya. Science, 362: 53-57

Corominas J, van Westen C, Frattini P, Cascini L, Malet J P, 
Fotopoulou S, Catani F, Van Den Eeckhaut M, Mavrouli O, Agliardi F, Pitilakis K, Winter M G, Pastor M, Ferlisi S, Tofani V, Hervás J, Smith J T. 2013. Recommendations for the quantitative analysis of landslide risk. Bull Eng Geol Environ, 73: 209-263

Craddock W H, Kirby E, Harkins N W, Zhang H, Shi X, Liu J. 2010. Rapid fluvial incision along the Yellow River during headward basin integration. Nat Geosci, 3: 209-213

Croissant T, Lague D, Steer P, Davy P. 2017. Rapid post-seismic landslide evacuation boosted by dynamic river width. Nat Geosci, 10: $680-684$

Croissant T, Steer P, Lague D, Davy P, Jeandet L, Hilton R G. 2019. Seismic cycles, earthquakes, landslides and sediment fluxes: Linking tectonics to surface processes using a reduced-complexity model. Geomorphology, 339: 87-103

Cruden D M, Lan H X. 2015. Using the working classification of landslides to assess the danger from a natural slope. In: Lollino G, Giordan D, Crosta G B, Corominas J, Azzam R, Wasowski J, Sciarra N, eds. Engineering Geology for Society and TerritoryVolume 2. Cham: Springer. 3-12

Cruden D M, Varnes D J. 1996. Landslide types and processes. In: Turner A T, Schuster R L, eds. Landslides-Investigation and Mitigation. Transportation Research Board, Special Report No. 247. Washington DC: National Academy Press. 36-75

Cui P, Zhou G G D, Zhu X H, Zhang J Q. 2013. Scale amplification of natural debris flows caused by cascading landslide dam failures. Geomorphology, 182: 173-189

Dai F C, Lee C F, Deng J H, Tham L G. 2005. The 1786 earthquaketriggered landslide dam and subsequent dam-break flood on the Dadu River, southwestern China. Geomorphology, 65: 205-221

Dai K, Li Z, Xu Q, Burgmann R, Milledge D G, Tomas R, Fan X, Zhao C, Liu X, Peng J, Zhang Q, Wang Z, Qu T, He C, Li D, Liu J. 2020. Entering the era of earth observation-based landslide warning systems: A novel and exciting framework. IEEE Geosci Remote Sens Mag, 8: 136-153

de Jesús Arce-Mojica T, Nehren U, Sudmeier-Rieux K, Miranda P J, Anhuf D. 2019. Nature-based solutions (NbS) for reducing the risk of shallow landslides: Where do we stand? Int J Disaster Risk Reduction, 41: 101293

Delgado F, Zerathe S, Audin L, Schwartz S, Benavente C, Carcaillet J, Bourlès D L, Team A. 2020. Giant landslide triggerings and paleoprecipitations in the Central Western Andes: The aricota rockslide dam (South Peru). Geomorphology, 350: 106932

Derbyshire E. 2001. Geological hazards in loess terrain, with particular reference to the loess regions of China. Earth-Sci Rev, 54: 231-260

Ding M T, Huang T, Zheng H, Yang G H. 2020. Respective influence of vertical mountain differentiation on debris flow occurrence in the
Upper Min River, China. Sci Rep, 10: 11689

Dong G, Zhang F, Ma M, Fan Y, Zhang J, Wang Z, Chen F. 2014. Ancient landslide-dam events in the Jishi Gorge, upper Yellow River valley, China. Quat Res, 81: 445-451

Ergu D, Kou G, Peng Y, Zhang M. 2016. Estimating the missing values for the incomplete decision matrix and consistency optimization in emergency management. Appl Math Model, 40: 254-267

Ernst J, Dewals B J, Detrembleur S, Archambeau P, Erpicum S, Pirotton M. 2010. Micro-scale flood risk analysis based on detailed 2D hydraulic modelling and high resolution geographic data. Nat Hazards, 55: 181-209

Faccenna C, Glišović P, Forte A, Becker T W, Garzanti E, Sembroni A, Gvirtzman Z. 2019. Role of dynamic topography in sustaining the Nile River over 30 million years. Nat Geosci, 12: 1012-1017

Fan X M, Scaringi G, Korup O, West A J, van Westen C J, Tanyas H, Hovius N, Hales T C, Jibson R W, Allstadt K E, Zhang L M, Evans S G, Xu C, Li G, Pei X J, Xu Q, Huang R. 2019. Earthquakeinduced chains of geologic hazards: Patterns, mechanisms, and impacts. Rev Geophys, 57: 421-503

Fell R, Corominas J, Bonnard C, Cascini L, Leroi E, Savage W Z. 2008. Guidelines for landslide susceptibility, hazard and risk zoning for land use planning. Eng Geol, 102: 85-98

Fu B, Tian T, Liu Y, Zhao W. 2019. New developments and perspectives in physical geography in China. Chin Geogr Sci, 29: 363-371

Fu B, Wang S, Liu Y, Liu J, Liang W, Miao C. 2017. Hydrogeomorphic ecosystem responses to natural and anthropogenic changes in the Loess Plateau of China. Annu Rev Earth Planet Sci, 45: 223-243

Geertsema M, Highland L, Vaugeouis L. 2009. Environmental impact of landslides. In: Sassa K, Canuti P, eds. Landslides-Disaster Risk Reduction. Berlin, Heidelberg: Springer. 589-607

Geertsema M, Pojar J J. 2007. Influence of landslides on biophysical diversity - A perspective from British Columbia. Geomorphology, 89: 55-69

Gill J C, Malamud B D. 2014. Reviewing and visualizing the interactions of natural hazards. Rev Geophys, 52: 680-722

Glade R C, Shobe C M, Anderson R S, Tucker G E. 2019. Canyon shape and erosion dynamics governed by channel-hillslope feedbacks. Geology, 47: 650-654

Gomes P I A, Aththanayake U, Deng W, Li A, Zhao W, Jayathilaka T. 2020. Ecological fragmentation two years after a major landslide: Correlations between vegetation indices and geo-environmental factors. Ecol Eng, 153: 105914

Gonzalez-Ollauri A, Mickovski S B. 2017. Shallow landslides as drivers for slope ecosystem evolution and biophysical diversity. Landslides, 14: 1699-1714 
Grafton R Q, Pittock J, Davis R, Williams J, Fu G, Warburton M, Udall B, McKenzie R, Yu X, Che N, Connell D, Jiang Q, Kompas T, Lynch A, Norris R, Possingham H, Quiggin J. 2013. Global insights into water resources, climate change and governance. Nat Clim Change, 3: 315-321

Gou J, Miao C, Duan Q, Tang Q, Di Z, Liao W, Wu J, Zhou R. 2020. Sensitivity analysis-based automatic parameter calibration of the VIC model for streamflow simulations over China. Water Resour Res, 56: e25968

Guo A, Chang J, Wang Y, Huang Q, Zhou S. 2018. Flood risk analysis for flood control and sediment transportation in sandy regions: A case study in the Loess Plateau, China. J Hydrol, 560: 39-55

Guo X, Gao R, Li S, Xu X, Huang X, Wang H, Li W, Zhao S, Li X. 2016. Lithospheric architecture and deformation of NE Tibet: New insights on the interplay of regional tectonic processes. Earth Planet Sci Lett, 449: 89-95

Guppy H B. 1880. The Yang-tse, the Yellow River, and the Pei-ho. Nature, 23: 99

Hamblin W K, Christiansen E H. 2004. Earth's Dynamic Systems. 10th ed. Hoboken: Prentice Hall. 309

He B S, Huang X L, Ma M H, Chang Q R, Tu Y, Li Q, Zhang K, Hong Y. 2018. Analysis of flash flood disaster characteristics in China from 2011 to 2015. Nat Hazards, 90: 407-420

He H M, Tian Y Q, Mu X M, Zhou J, Li Z B, Cheng N N, Zhang Q L, Keo S, Oeurng C. 2015. Confluent flow impacts of flood extremes in the middle Yellow River. Quat Int, 380-381: 382-390

Hirabayashi Y, Mahendran R, Koirala S, Konoshima L, Yamazaki D, Watanabe S, Kim H, Kanae S. 2013. Global flood risk under climate change. Nat Clim Change, 3: 816-821

Hoorn C, Wesselingh F P, ter Steege H, Bermudez M A, Mora A, Sevink J, Sanmartín I, Sanchez-Meseguer A, Anderson C L, Figueiredo J P, Jaramillo C, Riff D, Negri F R, Hooghiemstra H, Lundberg J, Stadler T, Särkinen T, Antonelli A. 2010. Amazonia through time: Andean uplift, climate change, landscape evolution, and biodiversity. Science, 330: 927-931

Hu Z B, Pan B T, Bridgland D, Vandenberghe J, Guo L Y, Fan Y L, Westaway R. 2017. The linking of the upper-middle and lower reaches of the Yellow River as a result of fluvial entrenchment. Quat Sci Rev, 166: 324-338

Hu Z, Pan B, Guo L, Vandenberghe J, Liu X, Wang J, Fan Y, Mao J, Gao H, Hu X. 2016. Rapid fluvial incision and headward erosion by the Yellow River along the Jinshaan gorge during the past 1.2 Ma as a result of tectonic extension. Quat Sci Rev, 133: 1-14

Hu Z, Pan B, Wang J, Cao B, Gao H. 2012. Fluvial terrace formation in the eastern Fenwei Basin, China, during the past $1.2 \mathrm{Ma}$ as a combined archive of tectonics and climate change. J Asian Earth
Sci, 60: 235-245

Huang R Q. 2009. Some catastrophic landslides since the twentieth century in the southwest of China. Landslides, 6: 69-81

Hungr O, Corominas J, Eberhardt E. 2005. Estimating landslide motion mechanism, travel distance and velocity. In: Hungr O, Fell R, Couture R, Eberhardt E, eds. Landslide Risk Management. London: CRC Press. $99-128$

Immerzeel W W, Lutz A F, Andrade M, Bahl A, Biemans H, Bolch T, Hyde S, Brumby S, Davies B J, Elmore A C, Emmer A, Feng M, Fernández A, Haritashya U, Kargel J S, Koppes M, Kraaijenbrink P D A, Kulkarni A V, Mayewski P A, Nepal S, Pacheco P, Painter T H, Pellicciotti F, Rajaram H, Rupper S, Sinisalo A, Shrestha A B, Viviroli D, Wada Y, Xiao C, Yao T, Baillie J E M. 2020. Importance and vulnerability of the world's water towers. Nature, 577: 364-369

Jia L, Hu D, Wu H, Zhao X, Chang P, You B, Zhang M, Wang C, Ye M, Wu Z, Liang X. 2017. Yellow River terrace sequences of the Gonghe-Guide section in the northeastern Qinghai-Tibet: Implications for plateau uplift. Geomorphology, 295: 323-336

Kappes M S, Keiler M, von Elverfeldt K, Glade T. 2012. Challenges of analyzing multi-hazard risk: A review. Nat Hazards, 64: 1925-1958

Kellogg K S. 2001. Tectonic controls on a large landslide complex: Williams Fork Mountains near Dillon, Colorado. Geomorphology, 41: $355-368$

Khan A, Gupta S, Gupta S K. 2020. Multi-hazard disaster studies: Monitoring, detection, recovery, and management, based on emerging technologies and optimal techniques. Int J Disaster Risk Reduction, 47: 101642

Kim H J, Lee J W, Yoon K S, Cho Y S. 2012. Numerical analysis of flood risk change due to obstruction. KSCE J Civ Eng, 16: 207-214

Kobayashi Y, Mori A S. 2017. The potential role of tree diversity in reducing shallow landslide risk. Environ Manage, 59: 807-815

Labat D, Goddéris Y, Probst J L, Guyot J L. 2004. Evidence for global runoff increase related to climate warming. Adv Water Resources, 27: $631-642$

Lan H X, Li L P, Wu Y M. 2013a. The role of rockfall intensity on its risk assessment. In: Wu F Q, Qi S W, eds. Global View of Engineering Geology and the Environment. London: CRC Press. $51-58$

Lan H X, Li L P, Zhang Y S, Gao X, Liu H J. 2013b. Risk assessment of debris flow in Yushu seismic area in China: A perspective for the reconstruction. Nat Hazards Earth Syst Sci, 13: 2957-2968

Lan H X, Martin C D, Lim C H. 2007. RockFall analyst: A GIS extension for three-dimensional and spatially distributed rockfall hazard modeling. Comput Geosci, 33: 262-279

Lan H X, Martin C D, Zhou C, Lim C H. 2010. Rockfall hazard analysis using LiDAR and spatial modeling. Geomorphology, 118: 213-223 
Lan H X, Zhou C H, Wang L J, Zhang H Y, Li R H. 2004. Landslide hazard spatial analysis and prediction using GIS in the Xiaojiang watershed, Yunnan, China. Eng Geol, 76: 109-128

Larsen I J, Montgomery D R. 2012. Landslide erosion coupled to tectonics and river incision. Nat Geosci, 5: 468-473

Lendering K, Schweckendiek T, Kok M. 2018. Quantifying the failure probability of a canal levee. Georisk-Assessment Manage Risk Engineered Syst Geohazards, 12: 203-217

Li L P, Lan H X, Peng J B. 2020. Loess erosion patterns on a cut-slope revealed by LiDAR scanning. Eng Geol, 268: 105516

Li W, Su Z H, van Maren D S, Wang Z B, de Vriend H J. 2017. Mechanisms of hyperconcentrated flood propagation in a dynamic channel-floodplain system. Adv Water Resources, 107: 470-489

Liu C, Shao X, Wu H, Li N, Qu T, Dotta G, Huang Y. 2018. Giant landslide displacement analysis using a point cloud set conflict technique: A case in Xishancun landslide, Sichuan, China. Int J Remote Sens, 40: 3247-3266

Liu W, He S M. 2018. Dynamic simulation of a mountain disaster chain: Landslides, barrier lakes, and outburst floods. Nat Hazards, 90: 757-775

Lopes L F, Oliveira S C, Neto C, Zêzere J L. 2020. Vegetation evolution by ecological succession as a potential bioindicator of landslides relative age in Southwestern Mediterranean region. Nat Hazards, 103: 599-622

Mériaux A S, Tapponnier P, Ryerson F J, Xu X W, King G, van der Woerd J, Finkel R C, Li H B, Caffee M W, Xu Z Q, Chen W B. 2005. The Aksay segment of the northern Altyn Tagh fault: Tectonic geomorphology, landscape evolution, and Holocene slip rate. J Geophys Res, 110: B04404

Miao C, Duan Q, Sun Q, Lei X, Li H. 2019. Non-uniform changes in different categories of precipitation intensity across China and the associated large-scale circulations. Environ Res Lett, 14: 025004

Milly P C D, Wetherald R T, Dunne K A, Delworth T L. 2002. Increasing risk of great floods in a changing climate. Nature, 415: $514-517$

Mulas M, Ciccarese G, Ronchetti F, Truffelli G, Corsini A. 2018. Slope dynamics and streambed uplift during the Pergalla landslide reactivation in March 2016 and discussion of concurrent causes (Northern Apennines, Italy). Landslides, 15: 1881-1887

Nunes Correia F, Castro Rego F, Da Grača Saraiva M, Ramos I. 1998. Coupling GIS with hydrologic and hydraulic flood modelling. Water Resources Manage, 12: 229-249

Pan B, Hu Z, Wang J, Vandenberghe J, Hu X. 2011. A magnetostratigraphic record of landscape development in the eastern Ordos Plateau, China: Transition from Late Miocene and Early Pliocene stacked sedimentation to Late Pliocene and Quaternary uplift and incision by the Yellow River. Geomorphology, 125: 225-238

Pan B, Hu Z, Wang J, Vandenberghe J, Hu X, Wen Y, Li Q, Cao B. 2012. The approximate age of the planation surface and the incision of the Yellow River. Palaeogeogr Palaeoclimatol Palaeoecol, 356357: 54-61

Pan B, Su H, Hu Z, Hu X, Gao H, Li J, Kirby E. 2009. Evaluating the role of climate and tectonics during non-steady incision of the Yellow River: Evidence from a 1.24 Ma terrace record near Lanzhou, China. Quat Sci Rev, 28: 3281-3290

Pedersen V K, Egholm D L. 2013. Glaciations in response to climate variations preconditioned by evolving topography. Nature, 493: 206-210

Peng J, Fan Z, Wu D, Zhuang J, Dai F, Chen W, Zhao C. 2015. Heavy rainfall triggered loess-mudstone landslide and subsequent debris flow in Tianshui, China. Eng Geol, 186: 79-90

Peng J, Zhang F, Wang G. 2017. Rapid loess flow slides in Heifangtai terrace, Gansu, China. Q J Eng Geol Hydrogeol, 50: 106-110

Peng J B, Wang S K, Wang Q Y, Zhuang J Q, Huang W L, Zhu X H, Leng Y Q, Ma P H. 2019. Distribution and genetic types of loess landslides in China. J Asian Earth Sci, 170: 329-350

Phillips C B, Jerolmack D J. 2016. Self-organization of river channels as a critical filter on climate signals. Science, 352: 694-697

Pourghasemi H R, Gayen A, Edalat M, Zarafshar M, Tiefenbacher J P. 2020. Is multi-hazard mapping effective in assessing natural hazards and integrated watershed management? Geosci Front, 11: 12031217

Preti F. 2013. Forest protection and protection forest: Tree root degradation over hydrological shallow landslides triggering. Ecol Eng, 61: 633-645

Qiu J. 2014. Landslide risks rise up agenda. Nature, 511: 272-273

Rodríguez-Peces M J, Azañón J M, García-Mayordomo J, Yesares J, Troncoso E, Tsige M. 2011. The Diezma landslide (A-92 motorway, Southern Spain): History and potential for future reactivation. Bull Eng Geol Environ, 70: 681-689

Ronchetti F, Borgatti L, Cervi F, Corsini A. 2010. Hydro-mechanical features of landslide reactivation in weak clayey rock masses. Bull Eng Geol Environ, 69: 267-274

Saharia M, Kirstetter P E, Gourley J J, Hong Y, Vergara H J. 2016. Accounting for rainfall spatial variability in prediction of flash floods. American Geophysical Union, Fall Meeting 2016, abstract \#H44B-05

Schuurman F, Ta W, Post S, Sokolewicz M, Busnelli M, Kleinhans M. 2018. Response of braiding channel morphodynamics to peak discharge changes in the Upper Yellow River. Earth Surf Proc Land, 43: $1648-1662$

Schwab M, Rieke-Zapp D, Schneider H, Liniger M, Schlunegger F. 
2008. Landsliding and sediment flux in the Central Swiss Alps: A photogrammetric study of the Schimbrig landslide, Entlebuch. Geomorphology, 97: 392-406

Sinha R, Bapalu G V, Singh L K, Rath B. 2008. Flood risk analysis in the Kosi river basin, north Bihar using multi-parametric approach of Analytical Hierarchy Process (AHP). J Ind Soc Remote Sens, 36: 335-349

Soldati M, Corsini A, Pasuto A. 2004. Landslides and climate change in the Italian Dolomites since the Late glacial. Catena, 55: 141-161

Song Y H, Yu H Q, Tan Y, Lv W, Fang D H, Liu D. 2020. Similarity matching of food safety incidents in China: Aspects of rapid emergency response and food safety. Food Control, 115: 107275

Storozum M, Lu P, Wang S, Chen P, Yang R, Ge Q, Cao J, Wan J, Wang H, Qin Z, Liu H, Park E. 2020. Geoarchaeological evidence of the AD 1642 Yellow River flood that destroyed Kaifeng, a former capital of dynastic China. Sci Rep, 10: 1-2

Su Q, Ren Z, Zhang H, Zhang P, Manopkawee P. 2019. The role of the Haiyuan Fault in accelerating incision rate of the Yellow River at the Mijia Shan Area, northeastern Tibetan Plateau, as revealed by insitu ${ }^{10} \mathrm{Be}$ dating. J Asian Earth Sci, 179: 276-286

Sun P, Wu Y, Wei X, Sivakumar B, Qiu L, Mu X, Chen J, Gao J. 2020. Quantifying the contributions of climate variation, land use change, and engineering measures for dramatic reduction in streamflow and sediment in a typical loess watershed, China. Ecol Eng, 142: 105611

Thierry P, Stieltjes L, Kouokam E, Nguéya P, Salley P M. 2008. Multihazard risk mapping and assessment on an active volcano: The GRINP project at Mount Cameroon. Nat Hazards, 45: 429-456

Tonini M, Cama M. 2019. Spatio-temporal pattern distribution of landslides causing damage in Switzerland. Landslides, 16: 2103 2113

Tung Y K, Mays L W. 1981. Optimal risk-based design of flood levee systems. Water Resour Res, 17: 843-852

Valenza J M, Edmonds D A, Hwang T, Roy S. 2020. Downstream changes in river avulsion style are related to channel morphology. Nat Commun, 11: 2116

van der Woerd J, Tapponnier P, Ryerson F J, Meriaux A S, Meyer B, Gaudemer Y, Finkel R C, Caffee M W, Zhao G G, Xu Z Q. 2002. Uniform postglacial slip-rate along the central $600 \mathrm{~km}$ of the Kunlun Fault (Tibet), from ${ }^{26} \mathrm{Al},{ }^{10} \mathrm{Be}$, and ${ }^{14} \mathrm{C}$ dating of riser offsets, and climatic origin of the regional morphology. Geophys J Int, 148: 356-388

Wang G L, Li T L, Xing X L, Zou Y. 2015. Research on loess flowslides induced by rainfall in July 2013 in Yan'an, NW China. Environ Earth Sci, 73: 7933-7944

Wang Y, Su Y. 2011. The geo-pattern of course shifts of the Lower Yellow River. J Geogr Sci, 21: 1019-1036
Wang Y J, Su Y J. 2013. Influence of solar activity on breaching, overflowing and course-shifting events of the Lower Yellow River in the late Holocene. Holocene, 23: 656-666

Wu L, Jiang J, Li G X, Ma X Y. 2018. Characteristics of pulsed runofferosion events under typical rainstorms in a small watershed on the Loess Plateau of China. Sci Rep, 8: 3672

Wu Q L, Zhao Z J, Liu L, Granger D E, Wang H, Cohen D J, Wu X H, Ye M L, Bar-Yosef O, Lu B, Zhang J, Zhang P Z, Yuan D Y, Qi W Y, Cai L H, Bai S B. 2016. Outburst flood at 1920 BCE supports historicity of China's Great Flood and the Xia Dynasty. Science, 353: $579-582$

Wu Y, Lan H. 2019. Landslide Analyst-A landslide propagation model considering block size heterogeneity. Landslides, 16: 11071120

Xu J, Li F. 2019. Response of lower Yellow River bank breachings to La Niña events since 924 CE. Catena, 176: 159-169

Xu X Z, Guo W Z, Liu Y K, Ma J Z, Wang W L, Zhang H W, Gao H. 2017. Landslides on the Loess Plateau of China: A latest statistics together with a close look. Nat Hazards, 86: 1393-1403

Yan R, Zhang X, Yan S, Zhang J, Chen H. 2018. Spatial patterns of hydrological responses to land use/cover change in a catchment on the Loess Plateau, China. Ecol Indicators, 92: 151-160

Yang S, Ding Z, Li Y, Wang X, Jiang W, Huang X. 2015. Warminginduced northwestward migration of the East Asian monsoon rain belt from the Last Glacial Maximum to the mid-Holocene. Proc Natl Acad Sci USA, 112: 13178-13183

Yu K K, Xu H, Lan J H, Sheng E G, Liu B, Wu H X, Tan L C, Yeager K M. 2017. Climate change and soil erosion in a small alpine lake basin on the Loess Plateau, China. Earth Surf Proc Land, 42: 12381247

Zhang D, Wang G, Luo C, Chen J, Zhou Y. 2009. A rapid loess flowslide triggered by irrigation in China. Landslides, 6: 55-60

Zhang F, Wang G, Kamai T, Chen W, Zhang D, Yang J. 2013. Undrained shear behavior of loess saturated with different concentrations of sodium chloride solution. Eng Geol, 155: 69-79

Zhang F, Yan B, Feng X, Lan H, Kang C, Lin X, Zhu X, Ma W. 2019. A rapid loess mudflow triggered by the check dam failure in a bulldoze mountain area, Lanzhou, China. Landslides, 16: 19811992

Zhang X, Fang X. 2017. Temporal and spatial variation of catastrophic river floodings in the Lower Yellow River from AD 960 to 1938. Holocene, 27: 1359-1369

Zhang Y, Huang C C, Shulmeister J, Guo Y, Liu T, Kemp J, Patton N R, Liu L, Chen Y, Zhou Q, Cuan Y, Zhao H, Wang N. 2019. Formation and evolution of the Holocene massive landslidedammed lakes in the Jishixia Gorges along the upper Yellow River: 
No relation to China's Great Flood and the Xia Dynasty. Quat Sci Rev, 218: 267-280

Zhang Z K, Wang S M, Yang X D, Jiang F C, Shen J, Li X S. 2004. Evidence of a geological event and environmental change in the catchment area of the Yellow River at 0.15 Ma. Quat Int, 117: 3540

Zhao B, Wang Y S, Chen M, Luo Y H, Liang R F, Li J. 2019. Typical characteristics of large-scale landslides in the transition belt between the Qinghai-Tibet Plateau and the Loess Plateau. Arab J Geosci, 12: 470

Zhao J Q, Zhang Q, Zhu X D, Shen Z X, Yu H Q. 2020. Drought risk assessment in China: Evaluation framework and influencing factors. Geogr Sust, 1: 220-228
Zhou Y, Liu Y, Wu W, Li N. 2015. Integrated risk assessment of multihazards in China. Nat Hazards, 78: 257-280

Zhuang J, Peng J, Wang G, Javed I, Wang Y, Li W. 2018a. Distribution and characteristics of landslide in Loess Plateau: A case study in Shaanxi Province. Eng Geol, 236: 89-96

Zhuang J Q, Peng J B, Xu C, Li Z H, Densmore A, Milledge D, Iqbal J, Cui Y F. 2018b. Distribution and characteristics of loess landslides triggered by the 1920 Haiyuan Earthquake, Northwest of China. Geomorphology, 314: 1-12

Zhuang Y, Yin Y P, Xing A G, Jin K P. 2020. Combined numerical investigation of the Yigong rock slide-debris avalanche and subsequent dam-break flood propagation in Tibet, China. Landslides, 17: 2217-2229

(责任编委: 崔鹏) 